\title{
The Contribution of the Fishermen's Guilds and the Agrarian Transformation Societies to the Sustainable Development Goals: The Case of the Canary Islands
}

\author{
Javier Mendoza Jiménez ${ }^{1, * \mathbb{C}}$, Beatriz Guzmán Pérez ${ }^{2}$, María Victoria Pérez Monteverde ${ }^{1}$ and \\ Cándido Román Cervantes ${ }^{1}$ (i) \\ 1 Faculty of Economics, Business and Tourism, La Laguna University, 38250 San Cristóbal de La Laguna, \\ Spain; mvperez@ull.edu.es (M.V.P.M.); croman@ull.edu.es (C.R.C.) \\ 2 Faculty of Economics, Europea University, Calle Inocencio García 1, 38300 La Orotava, Spain; \\ beatriz.guzman@universidadeuropea.es \\ * Correspondence: jmendozj@ull.edu.es; Tel.: +34-699-25-60-65
}

Received: 13 June 2020; Accepted: 10 July 2020; Published: 13 July 2020

\begin{abstract}
The Social Economy entities have been recognized as key agents for achieving the 17 Sustainable Development Goals (SDG) of the 2030 Agenda. To reach that, indicators are required to guide decision-making and facilitate accountability to citizens. Substantial progress has been made for the economic and environmental dimensions, but not for the social one, which is a particularly serious deficiency to support the social value that the Third Sector entities' have for the society. The objective of this study is to advance in this line, taking two organizations of the Social Economy that operate in the rural and marine environments of an important international tourist destination in Spain, the Canary Islands. The achieve this goal, the study uses the Social Value Polyhedral Model (SPOLY) of Social Accounting in the framework of the SDG to generate a system of relevant indicators that makes possible to project the particular contribution of these social actors, guide their action towards the global objectives, and render accounts in a transparent and understandable way to their stakeholders. The results show a common ground of contribution for both organizations (goals 8 and 17), but also the influence of the sphere of activity and the connections with the community.
\end{abstract}

Keywords: social economy; social accounting; fishermen guilds; sustainability; indicators; SDG

\section{Introduction}

The organizations that are part of the social economy are essential agents to carry out environmental and business sustainability plans at a global level. This assertion is supported by opinions not only from supranational institutions such as the one issued in 2015 by the United Nations but also by various publications that stress the same argument $[1,2]$. In the proximity ecosystems, sustainability plays an even more important role in development, and it is there where the social economy entities occupy a privileged place.

Rural and marine environments have the greatest impact on the communities in their environment, influencing the configuration of social networks and economic contacts. Not only because they balance the use of natural communal resources, aligned with the works of the Nobel Prize winner Elionor Ostrom [3], but also because they are consubstantial with the survival and the social well-being of the communities. The positive impact of social economy companies for the sustainability of the territories has been the subject of attention by various specialists [4,5], currently being one of the most controversial topics in the advances in the knowledge of social economy from an academic and scientific perspective. 
Decision making must be done through the verification of results that can be evaluated, and, even more, quantified. However, so far there are not enough indicators to perform quantitative approaches on the organizational performance of these entities with regard to sustainability. In recent years, a considerable effort has been made in various national and international spheres in the search for models that allow a standardized evaluation of the environmental, social, and sustainability actions carried out by organizations. The combination of the objectives of sustainability and the creation of social benefit requires entities to work in a more strategic way. On the other hand, society requires that economic organizations become humanized, satisfying the needs of citizens.

This work studies two social economy entities that can be a reference to channel strategies to the 2030 SDGs. An Agrarian Transformation Society (SAT), a hybrid associative business model in what refers to its corporate structure between a cooperative and the mercantile company $[6,7]$ and a fishermen's guild. Both carry out their productive activity in the Canary Islands and they are closely linked to the agricultural and marine environments in which they operate. The choice of both entities was not arbitrary. Until the mid-nineteenth century fishing and agrarian activity represented the main growth engines of the Canary archipelago before the arrival of tourism and port activity. The selection of entities responds to the need to show two examples that meet one of the fundamental requirements in the decalogue of the social economy: proximity. The proximity to consumers, partners, and workers who are part of companies.

In this way, the local aspect appears as a sign of identity and it is oversized by linking the productive activity with improving people's income and quality of life. The feeling of belonging to a community beyond the business organization implies emotional ties that can be quantified, as it will be seen throughout this work. This study emphasizes the importance of monetizing the social value of organizations and their connection with the ethical dimension, as well as with strategic decision-making for sustainability. All this has repercussions on local communities, on the environment, on public administrations, on interest groups, on families, on employment, and even on basic citizen income. The Social Accounting system allows organizations to communicate their contributions and achievements in sustainability. Its integration into the business strategy makes it easier for organizations to make decisions to advance in the deployment and achievement of the 2030 SDGs.

This work has been structured as follows. First, we contextualize the links between the SDGs and the social economy from a theoretical point of view, emphasizing the two entities that are the object of the analysis. We then evaluate the system of sustainable development indicators, to finally enter the empirical study of the research quantifying the contribution of each entity social accounting value variables to the SDGs. We finally provide the conclusions and future lines of research.

\section{Theoretical Framework}

\subsection{SDGs and the Entities of Social Economy}

Although it is true that the concern about the effects of economic progress on natural resources and society has a certain historical tradition $[8,9]$, it was not until the early seventies of the last century that more importance was given to the need for a change in the development model that made it possible for prosperity to be felt anywhere on the planet, and that was compatible with its conservation. It is precisely in these years when sustainability is introduced in the discourse on economic development it is attributed to Barbara Ward, founder of the International Institute for Environment and Development [10], combining two hitherto conflicting terms, sustainable development.

Two fundamental milestones gave conceptual support to this new development paradigm and contributed to its popularization: the United Nations Conference on the Human Environment (Stockholm, 1972), the first international institutional recognition of the need to aligning economic development with the conservation of resources, and the publication in 1980 of the World Conservation Strategy Living Resource Conservation for Sustainable Development, a pioneering document in the analysis of the actions to be implemented to achieve sustainable development. 
The interest in the approach of strategies that promoted this development model was taken up shortly afterward by the United Nations, entrusting this task to the United Nations Commission for Environment and Development (WCED), better known as the Brundtland Commission. The definition of sustainable development included in its Report as "one that meets the needs of the present generation without compromising the ability of future generations to meet their own needs" [11], in addition to having wide acceptance, it has been placed at the starting point of the debate on content and structure towards a more sustainable world [12].

The vagueness and indeterminacy of the definition [13] lead to multiple interpretations (seven years after the publication of the Brundtland Commission Report, [14] it accounts for more than 80 different interpretations of sustainable development that take as a starting point the definition formulated by the then Norwegian Prime Minister) and, consequently, to diametrically opposed proposals to achieve it. Specifically, it has sparked an intense discussion around two questions: what needs should it guarantee: only material needs, related to the standard of living and consumption of basic goods and services [15], or should it also enable the expansion of people's decision-making capacities [16], and what type of capital conditions growth [17], whether technological capital [18] or natural capital $[19,20]$.

From an institutional perspective, the development approach based on well-being and freedom has prevailed [21]. Thus, conceiving sustainable development as a human development that pursues the achievement of economic prosperity and the expansion of the fundamental freedoms of present and future generations in all its dimensions, without leaving anyone behind. In this current vision, sustainable development is considered in an integral way, unfolding in a triple aspect -economic, social and environmental-, and its achievement entails a manifestation, essentially, on a local scale $[22,23]$.

This institutional conceptual consensus at the international level has been accompanied by an unprecedented global commitment to urgently undertake actions that allow firm progress towards sustainable development, the 2030 Agenda. It is an action plan made up of 17 Objectives for Sustainable Development (SDGs) and 169 goals of universal application, related to five areas considered critical for humanity and the planet, and which guide the efforts of the countries to achieve a sustainable world in the year 2030. The 17 SDGs established represent progress. In terms of achieving sustainable development-taking into account the ambiguity present in the definition of the Brundtland Report [11].

The following two could be highlighted as distinctive elements of the 2030 Agenda. Firstly, the recognition that, to achieve the objectives and goals set, decisive action by institutions and governments and the involvement of private agents are required. Secondly, the need to have a system of indicators that makes it possible to monitor the progress made at different scales of aggregation, guide the action of the different decision-making units and, ultimately, enable accountability to the citizenship.

Social economy entities, in line with the definition of [24] are conceived as "organizations with explicit social or environmental objectives guided by principles and practices of cooperation, solidarity, ethics and democratic self-management" [25] and have been recognized as decisive entities in the global action plan aimed at achieving sustainability, both institutionally [22] and academically [26], fundamentally for the following four reasons.

Firstly, because its operating principles are aligned with the values that guide action towards a more sustainable planet, so they could promote the intended human and integral development [27]. In this regard, the defining features of the Third Sector entities would make possible the expansion of the freedoms of present and future generations [28], having derived, from a theoretical point of view, the effects that such principles and values would have on utility social [29] and sustainable development [30]. In particular, the prevalence of people and work before the capital, social purpose, or the democratic governance that characterize them would allow these organizations to exercise social, economic, and political functions in the economic system that would contribute to achieving sustainable growth and socially inclusive [2,31]. 
Second, the patterns of production, finance, and exchange of social economy entities prioritize not only people but also respect for the natural environment. Hence, it is estimated that their actions would holistically and synergistically reinforce the different dimensions of sustainability, constituting an alternative to the unbalanced and exclusive development model derived from the centrality of the economic pillar [1].

A third reason why these agents are considered critical to achieving the challenges posed is related to the area in which they carry out their activity. Their roots in the local economy and the community in which they operate would favor, at this territorial level, inclusive and human development $[4,32]$. A very important aspect to make effective the development centered on people is the consideration of local demands and needs and their achievement in practice.

Finally, the potential of the social economy towards the SDGs can also be explained bearing in mind that it acts not only through the entities that make it up, but also through the civil society that is involved in them, and that has been urged to collaborate to achieve such objectives [24,31]. The United Nations Interdisciplinary Working Group on Social and Solidarity Economy has remarked the specific goals that, within each of the SDGs, would be reinforced through its action [27].

\subsection{Assessment of the Contribution to the SDG: Particularities of the Social Economy}

To fulfill the commitments acquired in the area of sustainable development it is necessary to have indicators, or "symbolic representations designed to communicate a property or tendency of a complex system or entity" [33] that are a faithful reflection of the degree of sustainability achieved. It is critical that the selected metrics provide information in all three dimensions, and guide action in the right direction, at different levels of disaggregation and decision. They are important catalysts and can change behavior, as they "arise from values and create values" [34].

However, the design of sustainability indicators entails certain difficulties, mainly because the ultimate goals are related to subjective and qualitative aspects, and are dimensions dominated by the Humanities [33]. It would seem, therefore, convenient to move from an approach characterized by the prevalence of objective and quantitative metrics to another one in which greater prominence is given to indicators that, although being subjective -for measuring qualitative variables-, are rigorous and reliable. "Continuing to measure what is easy to measure instead of what is important to people, will continue to guide action towards a world with a lot of quantity and low quality" [34].

Since the United Nations Conference on Environment and Development (Rio de Janeiro, 1992), efforts have been made to specify the criteria that must be met by the metrics of sustainable development [35]. Among them, it could be highlighted that, in addition to being relevant and precise, they must be understandable to citizens, transparent, and focused on people [22]. Special emphasis has also been placed on ensuring that the design process is democratic and participatory. The integration of this ethical component in the construction phase of the indicator guides the measurement towards the ultimate goal-human well-being and intra-generational equity [33,34].

Substantial progress has been made in determining metrics on a global scale, with an indicator framework established to assess progress towards the 17 SDGs and their 169 targets [35]. Although this approach represents an "unprecedented statistical challenge" [36], the relevance of the selected metrics has been questioned, as well as the manageability of the data [37], expressing the need to achieve global agreements to establish a homogeneous implementation system [38].

A widely accepted reference model for the design of sustainability indicators at the organizational level is that of the theory of the value chain of change [39], a chain of causality by which the activities of an entity translate into economic impacts, environmental and social. From an institutional perspective, this theory has been taken as a framework to guide organizations in the process of selecting sustainable performance indicators, in its three dimensions $[40,41]$. The desirable indicators, in this logical model, are referred to as the impacts, although understanding what activities of the organization have caused them. This involves combining metrics of a retrospective type, or those measuring results and impacts, with others of a prospective nature, that predict results and impacts. 
To facilitate the assessment of the organizations' impact and guide their activities towards the SDGs, the alliance between the United Nations Global Compact, GRI, and the World Business Council for Sustainable Development (WBCSD) has established an inventory of indicators, taken from widely recognized standards. Entities can directly select the metrics they consider most relevant or use them as an inspiration to define their own. In any case, for the selection and design of such indicators, the partnership recommends involving stakeholders, although the procedure for carrying it out is not standardized. The entities of the agri-food sector have a specific guide for the deployment of their activity towards the SDGs, in which particular metrics are proposed [42], mostly referring to inputs and activities, and results for the environmental dimension.

On the other hand, the development of indicators for the social aspect is in a more incipient phase. In the last years' generic systems to determine the social impact at the organizational level have appeared, such as the Balance of the Common Good [43], Impact Assessment B [44], the LBG model, the Capabilities Index [45], the Impact Measurement Framework [46], the SPOLY model [47], or the Social Return on Investment. The metrics that these systems propose to refer to different links in the impact value chain while requiring a different degree of participation from the entity's interest groups [48].

From an academic perspective, there have been various works that address the analysis of the contribution of business organizations to the SDGs Those include not only multinationals $[49,50]$ but also small and medium-sized companies [51], and spread through diverse productive sectors, like manufacturing [52] or agriculture [53].

\subsection{Social Economy in Spain: Fishermen's Gilds and Agrarian Transformation Societies}

Bearing in mind that the social economy "forms a space of economic reality made up of private organizational forms created by people to respond to their own social demands, to their substantive problems and to their social aspirations", its concretion in each country and moment of time depends on the types of needs to be covered and the economic problems that are not satisfactorily resolved either by the State or by the traditional business sector [24].

In Spain, the different forms of social economy entities that currently exist are the result of their particular historical, social, political, cultural, and economic trajectory $[54,55]$. The agents of the social economy have a common regulatory framework, the Law 5/2011, of March 29, on the Social Economy, which expressly recognizes in its article 4 fishermen's guild and SATs as families of the social economy, because they are governed for the guiding principles of this sector.

Fishermen's guilds have a long historical tradition in Spain, the first of which is known to date back to the 11th century [56,57]. Generally, it was the fishermen themselves who promoted their creation to facilitate the exercise of their trade through collaborative practices. Therefore, performing community functions for the benefit of their associates and participating in the development of a marginal part of the population with limited resources, linked to the exploitation of the sea and linked to small artisanal fisheries [58].

Currently, the guilds are defined in article 45 of Law 3/2001, of March 26, on State Maritime Fisheries, as amended by Law 33/2014, of December 26, with the following characteristics: corporations under public law, non-profit, representative of the economic interests of its partners, endowed with full legal personality and the capacity to act for the fulfillment of its purposes. Their regulation is under the responsibility of the Autonomous Communities. This regulatory framework recognizes that the guilds carry out certain specific functions of an economic, social and ecological nature that could be grouped into two general categories: one that enables these agents to participate in the governance of fisheries, and others that serve the social purpose that characterizes them (Table 1). 
Table 1. Fishermen's Guilds and Agrarian Transformation Society (SATs): general characteristics.

\begin{tabular}{lll}
\hline & \multicolumn{1}{c}{ Fishermen's Guild } & \multicolumn{1}{c}{ Agrarian Transformation Societies } \\
\hline $\begin{array}{l}\text { Regulatory } \\
\text { framework }\end{array}$ & $\begin{array}{l}\text { Ley 3/2001, de 26 de marzo, de Pesca Marítima del } \\
\text { Estado, modificada por la Ley 33/2014, de 26 de } \\
\text { diciembre }\end{array}$ & $\begin{array}{l}\text { Real Decreto 1776/1981, de 3 de agosto, por el } \\
\text { que se aprueba el Estatuto que regula las } \\
\text { Sociedades Agrarias de Transformación, BOE } \\
\text { núm. 194, de 14 de agosto }\end{array}$ \\
\hline \multirow{2}{*}{ Definition } & $\begin{array}{l}\text { Non-profit public law corporations, representative of } \\
\text { the economic interests of its partners, endowed with } \\
\text { full legal personality and the capacity to act for the } \\
\text { fulfillment of their purposes. }\end{array}$ & $\begin{array}{l}\text { Civil societies of economic-social purpose for } \\
\text { the production, transformation and } \\
\text { commercialization of agricultural, livestock or } \\
\text { forestry products, the realization of } \\
\text { improvements in the rural environment, } \\
\text { agrarian promotion and development and the } \\
\text { provision of common services that serve that } \\
\text { purpose. }\end{array}$ \\
\hline
\end{tabular}

\begin{tabular}{|c|c|c|c|c|c|}
\hline \multirow[t]{2}{*}{ Functions } & $\begin{array}{l}\text { Fishing } \\
\text { Governance }\end{array}$ & $\begin{array}{l}- \\
- \\
- \\
- \\
- \\
- \\
- \\
- \\
-\end{array}$ & $\begin{array}{l}\text { Duty to inform/right to } \\
\text { inform the } \\
\text { competent administrations. } \\
\text { Participate in the first sale } \\
\text { of fishery products. } \\
\text { Propose improvements to } \\
\text { the conditions of sale and } \\
\text { revaluation of production. } \\
\text { Promote the } \\
\text { transformation, } \\
\text { conservation and } \\
\text { promotion of } \\
\text { fishery products. } \\
\text { Ensure compliance with } \\
\text { fisheries regulations. } \\
\text { Provision of } \\
\text { public service. } \\
\text { Facilitate the } \\
\text { implementation of the } \\
\text { common fisheries policy. } \\
\text { Maintain the status of } \\
\text { demand concessions. } \\
\text { Collaborate with fisheries } \\
\text { and oceanographic } \\
\text { research organizations. }\end{array}$ & Economic goals & $\begin{array}{l}\text { Production, } \\
\text { transformation and } \\
\text { distribution of } \\
\text { agricultural, livestock } \\
\text { and forestry products. }\end{array}$ \\
\hline & Social goals & $\begin{array}{l}- \\
- \\
-\end{array}$ & $\begin{array}{l}\text { Advice and } \\
\text { guide members. } \\
\text { Provide social, } \\
\text { recreational, cultural, and } \\
\text { similar services. } \\
\text { Promote partner } \\
\text { training activities. }\end{array}$ & Social Goals & 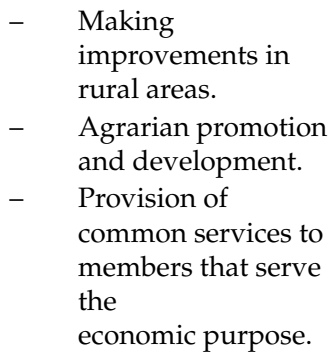 \\
\hline
\end{tabular}


Table 1. Cont.

\begin{tabular}{|c|c|c|c|}
\hline & Fishermen's Guild & & Agrarian Transformation Societies \\
\hline $\begin{array}{l}\text { Specific } \\
\text { characteristics - } \\
\text { as Social } \\
\text { Economy } \\
\text { entity }\end{array}$ & $\begin{array}{l}\text { Specialization in a single sector, the } \\
\text { fishing industry. } \\
\text { Obligation to collaborate with the public sector. }\end{array}$ & $\begin{array}{l}- \\
-\end{array}$ & $\begin{array}{l}\text { In general, adoption of agreements } \\
\text { following the cooperative principle "1 } \\
\text { person, } 1 \text { vote". } \\
\text { Adoption of agreements that imply } \\
\text { financial obligations for the members } \\
\text { based on proportionality with respect to } \\
\text { the contributions to the share capital, if } \\
\text { established by the Statutes. } \\
\text { Distribution of benefits based on the } \\
\text { contribution made by the partner to the } \\
\text { share capital. } \\
\text { Transmission of the condition of } \\
\text { membership inter vivos or by inheritance } \\
\text { only in the event that the substitute meets } \\
\text { qualities similar to those of the former and, } \\
\text { in addition, the General Assembly } \\
\text { approves it. }\end{array}$ \\
\hline
\end{tabular}

Taking into account the guiding principles of the Social Economy entities [59], those of the prevalence of people, application of the results based on work, internal solidarity and independence from the public powers are present in them. By their nature, they fall within the hardcore of the social economy, made up of cooperatives, mutual societies, and associations [60]. Two fundamental aspects distinguish them from other organizations of a social nature: the specialization in a single sector, the fishing sector, and the obligation to collaborate with public authorities.

As representative entities of the interests of the artisanal and inshore fishing branch, they are a key part of the Blue Growth Initiative the Action program of the Food and Agriculture Organization of the United Nations (FAO) that supports global sustainability through measures that specifically promote the sustainability of the oceans and the Blue Growth Strategy-a long-term strategy of the European Union to support the sustainable growth of the marine and maritime sectors [61], for supplying food, income, and employment in a sustainable way-due to the intrinsic characteristics of the productive activity that they carry out $[62,63]$ —and because their participation in the governance of fisheries allows the integration of traditional ecological knowledge of fishermen into short-term operational management and the preparation and long-term planning of fisheries policies.

The SATs have an organizational and management formula based on associationism, specific to the Spanish legal system -although in France there is an associative figure that has similarities to the Spanish one, called Groupements Agricoles d 'Exploitation en Comun [64]. Its regulatory framework, Royal Decree 1776/1981 and its corresponding Order configure them as civil companies in the agricultural sector, for purposes of an economic and social nature (Table 1).

This associative figure has its antecedents in the Union Groups of Agrarian Colonization (GSC), created after the Spanish Civil War to carry out improvement activities in rural areas and promote agricultural works and activities with the help of the State. Various orders and subsequent circulars expanded their field of action [6], giving them a corporate, cooperative, and mercantile nature to increase productivity in the Spanish agricultural sector [7].

The GSCs were widely disseminated [65], although changes were made to their regulations to reflect the new political and economic reality in the country. The SATs came to replace such groups, designing their statute based on one of the extinct union groups. Therefore, elements of cooperation and commercial entities converge in it [7] (Table 1), among which the breach of the cooperative principle of democratic decision-making-in agreements that imply economic obligations for members-could be highlighted, that of participation in the capital, and the prevalence of the figure of the partner over his financial contribution. 


\section{Fishermen's Guilds and SATs in the Canary Islands}

\subsection{Geographical Context}

The geographical context of the fishermen's guilds and SATs is the Canary archipelago, an outermost region of the European Union. The Canary Islands is an Autonomous Community of the Kingdom of Spain, located off the north-west coast of the African continent-approximately $4^{\circ}$ from the Tropic of Cancer-and $100 \mathrm{~km}$ from the border between Morocco and Western Sahara. Its origin is volcanic, it has eight main islands, three islets, and two rocks, and $1379 \mathrm{~km}$ of coastline length $-18.38 \%$ of the national total [66]. Its jurisdictional waters border three national maritime borders, Portugal, Morocco, and Western Sahara, having the largest Exclusive Economic Zone on a national scale [67].

This insular group is located in the passage of the cold maritime current of the Canary Islands, which regulates the climate and determines the oceanographic characteristics of the area. It is populated by a large number of endemic and migratory or transboundary species and is considered a unique ecosystem of global importance. A particular feature of this current is that it has an ascension zone, along the west African coast, where deep, nutrient-rich cold waters arrive, which stimulate primary productivity and, therefore, that of other levels. of the marine food chain [68]. The productivity of the oceanic waters that surround the islands is lower, due to their oligotrophic conditions and the narrowness of the insular continental shelf, due to the volcanic origin of the archipelago [69].

Regarding the climate of the Canary archipelago, in general, it is dry and humid subtropical, although it has microclimates, or accentuated climatic differences over short distances, which promote great ecological diversity and landscape contrasts. Its thermal conditions are mild, with few seasonal contrasts throughout the year. These characteristics have shaped this island complex as an important international tourist destination, having received in 201913.1 million international travelers [70]. The characteristic activities of tourism are the main engine of the regional economy, thus, the contribution of the tourism sector to the GDP of the Canary archipelago reached $35 \%$ in 2018 [71].

\subsection{Study Cases}

\subsubsection{Fishermen's Guild}

The Fishermen's Guilds, conceived as unions of fishermen who gathered around an entity or organization, try to achieve the objectives of the activity they carry out [72]. These entities, despite having received less attention in the field of social economy, have been explicitly recognized as key pieces in comprehensive sustainability [73].

The guilds make a comprehensive contribution to the local community and generate social value for sustainability in the management of these regional organizations. Thus, they have shown a high capacity for self-organization and internal conflict resolution, managing to establish forms of relationship between their members and with common resources in an attempt to control fishing effort and agree on gear and practices to use in the exercise. Fishing, mostly inshore or artisanal [63,74].

Among the academic studies on the guilds, the socio-environmental management they carry out in general [75], their socio-economic influence on fishing [76], and even collaboration with the scientific community [77] stand out. In particular, to the extent that the effective participation of these organizations in the governance of fisheries allows those who practice this profession to obtain a greater economic income, it would also reinforce the economic aspect of sustainability [73].

Fishing activity has a low economic weight in the Canary Islands' productive structure. According to the 2019 Annual Report of the Economic and Social Committee Council of the Canary Islands on the economic, social and labor situation of the Canary Islands in 2018 [78], and based on data from the National Institute of Statistics (INE), Spanish Regional Accounting (CRE) 2018, the production of the fishing sector in the Canary Islands in 2017 (latest available data), it is 13,837,790 kg in fresh 
fishing (8.76\% more than the previous period in monetary terms), 7,818,477 $\mathrm{kg}$ in aquaculture and $170,777 \mathrm{~kg}$ in frozen.

In reference to exports of fish, crustaceans, mollusks, and other aquatic invertebrates, they are estimated at 124.33 million euros in 2018 , a decrease of $24.93 \%$ compared to the previous year [79]. The public funds for this subsector in the 2014-2020 period amount to 93.7 million euros, of which 60.9 million belong to the POSEICAN-Pesca program.

As for the fleet used to extract these resources, according to data of the Ministry of Agriculture and Fisheries, Food and Environment (MAPAMA) Annual Report of 2019 on the Activity of the Spanish Fishing Fleet, the characterization of the active fleet of 2018 by modality census as of 12/31/2018, with respect to the Canary Islands, is as follows: total number of vessels in the national fishing ground, 589. Among them, minor arts $537(91 \%)$ and pole-and-line tuna vessels $52(9 \%)$.

It should be noted that the importance of artisanal and inshore fishing in the whole of the fishing activity in the Canary Islands is a reflection of a long historical tradition in the region [69,80], and is part of the identity of many of its towns [68]. According to the 2007-2013 National Strategic Plan of the European Fisheries Fund [81], 30 of the 89 Canary Islands municipalities are dependent on this productive activity.

The sailors and shipowners of the Canary Islands autonomy, like those of the rest of Spain, voluntarily associate themselves with the active fishermen's brotherhoods which, according to data from the Ministry of Agriculture, Livestock and Fisheries of the Canary Islands Government, amount to 25 in 2018. In Tenerife, the largest of its islands, are located 10 of these social economy entities, which represents $40 \%$ of the total in the archipelago.

Of the fishermen's guilds that remain active in this Autonomous Community, after having carried out interviews to check their availability, one of them was selected as a particular case study. This guild is located on the southern coast of the island of Tenerife, with territorial jurisdiction in two municipalities dependent on fishing activity [81]. Within its territorial scope are located six ports, managed by different administrative levels. The venue and the fiscal address of the analyzed entity are located in a port with a complete endowment of infrastructures, optimal docking conditions, anchoring and shore facilities, and traffic of fishing boats of the largest in the area.

The brotherhood census is made up of 138 members, mostly sailors $(60.1 \%)$, from the minor gear fishing segments (79\%) and tuna vessels (31\%). 43.5\% of associates have been affiliated for more than 20 years, and $39.9 \%$ of members registered within the last ten years. In the ports located within its jurisdiction, a total of 67 vessels of minor gears ( $88 \%)$ and tuna vessels $(12 \%)$ are registered, predominating those of length less than $10 \mathrm{~m}(64 \%)$.

The statutes establish as governing bodies 16 members in the general meeting and 6 members in the council, in addition to the senior employer and the senior vice-employer. The organizational structure is completed with two labor workers. The brotherhood's public concessions are the crane, the travel lift, and the repair shop, whose vigilance and maintenance must be guaranteed.

It does not have a first sale concession and, in the port where it is located, there is also no place that allows the registration of fresh fish. The associates of the entity with a base of operations in that port must transport the fishery products for their labeling to start their commercialization autonomously. The entity, on the one hand, obtains the income from the fees paid by the partners, the provision of the dry dock service and the sale of fishing equipment. On the other hand, its volumes of purchases from local suppliers are scarce and it contracts credit services.

The guild deals with its daily operations by allocating impairments due to uncollectible commercial loans on an individual basis, which it later reverts to the part collected or reclassifies to clients. The guild faces eviction since 2010, with the dependencies in which it is located belonging to the provincial Port Authority. This financial weakness prevents it from accessing the subsidy system and developing actions of social and cultural interest for its members and the local community. 


\subsubsection{Agrarian Transformation Society}

The owners of agricultural holdings, agricultural workers, or legal persons with agrarian purposes associate in the Canary Islands using, among others, the formula of the Agrarian Transformation Societies. In 2018, 440 of these entities were registered, 3.6\% of those existing in Spain [82]. Farmers and ranchers in the archipelago use this form of associationism more than the cooperative: of the social economy entities in the agricultural sector, $79 \%$ are SAT and the remaining $21 \%$ are agricultural cooperatives [83].

The weight of agriculture in the economic-productive structure of the archipelago has been systematically reduced in recent years: in the period 2009-2017, the share of agricultural production in regional GDP has decreased by two-tenths of a percentage (from $1.47 \%$ to $1.26 \%$ ), and that of agricultural employment as a whole, by 1.5 tenths of a percentage (from $2.75 \%$ to $2.59 \%$ ) [84].

Likewise, when comparing the data from 1999 and 2009 referring to population density and cultivated area of the 88 municipalities of the archipelago [82], it is observed, first of all, that in 24 regions with an agricultural tradition, and close to tourist spots, the extent of farmland has been reduced and the concentration of population has increased. Secondly, that in 7 rural municipalities, far from tourist spots and capital cities, agricultural land has ceased to be cultivated and the population has been lost.

After having carried out interviews with different agrarian transformation organizations to assess their availability, one of the SATs of the Canary Islands, located on the northern side of the island of Tenerife, was taken as a case of analysis. It is an entity that traditionally focuses on sustainability, developing actions of a social and environmental nature. Recently, it has begun to be held accountable to citizens according to customary frames of reference. Its responsibility with the consequences derived from its activity goes beyond the internalization of negative impacts, trying to promote, through its actions, the generation of value for society.

Originally established in 1914 as an agricultural union, its corporate purpose is the marketing of agricultural products. Its census is made up of a total of 229 members, individuals, and legal entities that produce fruit and vegetables. The entity facilitates the commercialization and distribution of the agricultural production they obtain, and the collection and transport to their dependencies. Purchasing policy is characterized by the preferential choice of regional organizations with responsible business management.

It is a medium-sized agrarian society, made up of 112 workers on average per year. SAT's human resources practices seek to promote quality employment, promote diversity, equality, and the reconciliation of their work, family, and personal life, contribute to continuous training and personal development with equal opportunities, and take care of the health and safety of workers.

The organization has certifications in food safety, ISO 22,000, and in environmental management, ISO 14001, collaborates frequently and fluently with traditional media and online social networks. It also supports entities of a public nature and the third sector for the development of social, educational causes, or values aligned with sustainability.

\section{Methodology}

In this work, the SPOLY model [85] is used as a framework to make visible and measure the contribution of the SAT and the Guild to the SDGs. It is a specific model of Social Accounting [86], which complements and expands the accounting information system, both in the nature of the value considered and in the interest groups contemplated. It is characterized by objectifying in a single monetary measure the economic and social value attributable to management, the integrated social value or blended value [87], and satisfying the information demands of stakeholders [88].

In the field of social economy, this accounting information system has been used to propose specific metrics of the socio-economic impact of various families of entities of a social nature, such as cooperatives [89], foundations and other non-profit organizations [90]. Within the research carried out 
in this field, the relationship between the value variables generated by organizations and the SDGs is still in a very early stage, with hardly any studies addressing it.

The SPOLY model is developed based on a cost-benefit analysis [91] and the following four methodological hypotheses:

(i) a participatory action research process [92], characterized by the combination of theory and practice and which involves solving a problem from the participatory construction of new knowledge,

(ii) an approach to the concept of social value from the theory of stakeholders [87], which enables the social value that an entity generates to those who participate and are affected by its activity to be specified,

(iii) the phenomenological paradigm [93-95], which involves considering social value as a construct elaborated subjectively by the stakeholders who are recipients of said value, and

(iv) the hypothesis of fuzzy logic [96,97], which makes it possible to monetize social value by making use of instruments typical of fuzzy set systems, such as similarity as an allocation criterion between the two sets of mental objects or the application of the criterion [98] for value selection.

The blended value in this model is made up of two components, the social market value and the specific or non-market social value. The first of them collect the social value that the organization generates with the performance of its economic activity, transfers it as a counterpart to a real market price. This value includes generated and distributed value both directly [85] and indirectly-through input purchases [91]. For the determination of this first component of the integrated social value, metrics are used in relation to outcomes (direct and indirect), common to all organizations. The specific or non-market social value is the value transferred by the organization to its stakeholders without a counterpart to the real market price.

For the quantification of the integrated social value, a standardized procedure [85] consisting of four stages is followed. First, a working team is formed, made up of external experts and members of the organizations involved. Subsequently, the entity's interest groups are identified-the individuals or groups that receive some type of value generated by the organization, monetary or not. In the third stage, the variables of perceived value are identified, establishing the ways in which the organization creates value for its stakeholders. In accordance with the phenomenological perspective, this analysis is carried out through in-depth interviews. The analytical structuring of the information collected in these interviews, after having triangulated it with the internal and external documents of the organization, is carried out by delimiting thematic areas of perceived value. This is done by integrating synonymous, related, or strongly similar expressions-, expressing them in terms of third, and reformulating them in scientific language [99]. The fourth stage involves quantifying and monetizing the value variables found, identifying the organization's outputs linked to the value variables, selecting the proxies-attention to the socio-temporal context in which the outputs are generated-, and using the formula o the corresponding algorithm [86].

The SPOLY model of Social Accounting is an especially appropriate system to evaluate the contribution of SATs and fishermen's guild to the SDGs. The subjective approach for objectifying the social value on which it is based, being conceptually aligned with the philosophy of sustainability, allows, through a standardized and scientifically based process, the identification of stakeholders, the analysis of their interests and perceptions, and the approach of indicators of social sustainability for the organization-in whose design the stakeholders themselves intervene. This model guarantees compliance with the criteria of the relevance of the indicator, transparency, stakeholder participation, soundness, and methodological rigor. However, its limitations must be taken into account. In particular, the subjectivity and discretion present in the process, together with the fact that it is still in a developing phase. That implies that there are insufficiently standardized methodological aspects and conditions the applicability of the results to a certain organization at a specific moment in time. Additionally, comparability between organizations is not possible when their characteristics are not similar. 
To determine the contribution of each of the study entities to the SDGs, we start with the variables of the social value of non-market identified for the guild [100] and the SAT [101]. This option has been chosen to estimate considering that this component of blended value reflects the qualitative differences between organizations. Subsequently, each variable is included in the SDGs and, where appropriate, in the corresponding target, taking into account the nature of the variable itself. The quantification in monetary terms of the value variables in the two aforementioned studies allows us to express in this same unit of measurement the contribution to the SDGs of each of the entities, both in absolute values and in percentage. Finally, the relationship of value variables with the stakeholders is taken into account to show the contribution to the SDGs, taking the stakeholders as the center. Throughout the analysis, a comparison will be made between both entities to expose the similarities and differences between them.

\section{Results}

\subsection{The Correspondence between Value Variables and the SDGs}

The process to determine the value variables in each organization and their description can be found at $[100,101]$. Within the non-market social value were identified 7 value variables for the guild and 18 for the SAT as can be seen in Table 2. An expanded definition of each of the variables can be seen in Appendix A.

Table 2. Value variables of each organization.

\begin{tabular}{ll}
\hline Value Variables Fishermen's Guild & Value Variable SAT \\
\hline Divulgation & Social response \\
Support & Divulgation \\
Emotional value & Employability \\
& Sustainability \\
& Fostering informal and collaborative networks \\
& Confidence and fluidity of communication \\
& Job recognition \\
& Training \\
& Flexibility \\
& Decision power \\
& Gender equality \\
& Cooperative spirit and internal solidarity \\
& Ethical choice of providers \\
\hline Ecological and sectorial knowledge & Sustainability \\
Price advantage & Economic security \\
Service & Expanding economic opportunities \\
Brand strength & Reputation and expansion of the market \\
& Sustainability \\
& Proactivity and innovation \\
\hline
\end{tabular}

This primal allocation of the variables into the SDG followed two criteria: first, the similarities of the concept described by the variables with existing cases already classified within international publication such as $[27,102,103]$. The previous works of $[104,105]$ on the description of the SDGs were also established as a reference framework. Secondly, it was taken into account not only the description of the Goals (that are generally less concrete) but also that of the targets including in the proposed Goal, which are normally more specific.

To classify the variables into the 17 SDGs set by the United Nations, one of the authors prepared the first proposal for each organization. This first proposal was after sent to the rest of the authors that evaluated it and proposed changes according to the scheme that can be seen in Table 3. The fitting of each variable into the proposed Goal was evaluated from 1-5 (being 1 does not fit at all and 5 fits 
perfectly) and an alternative classification could be proposed and justified. In case the beginning classification did not reach at least 4 over 5 points for all the authors, it was revised until consensus within the authors was reached.

Table 3. Assessment table for the first proposal.

\begin{tabular}{lllll}
\hline $\begin{array}{c}\text { Value Variable } \\
\text { SAT }\end{array}$ & Proposed Goal & $\begin{array}{c}\text { Is It Adequate? } \\
\text { (from 1 to 5) }\end{array}$ & Reasons Why Not & Alternative \\
\hline $\begin{array}{l}\text { Variable } 1 \\
\text { Variable }\end{array}$ & $\begin{array}{l}\text { Goal X } \\
\text { Goal X }\end{array}$ & & \\
\hline $\begin{array}{c}\text { Value variable } \\
\text { Guild }\end{array}$ & Proposed Goal & $\begin{array}{c}\text { Is It adequate? } \\
\text { (From 1 to 5) }\end{array}$ & Reasons why not & Alternative \\
\hline $\begin{array}{l}\text { Variable } 1 \\
\text { Variable }\end{array}$ & Goal X & & \\
\hline & Goal X & & & \\
& & $* 1=$ does not fit at all, $5=$ it fits perfectly.
\end{tabular}

\subsubsection{Fishermen's Guild}

As can be seen in Figure 1, the value variables resulting from the guild's study are limited to three SDGs. Of the 7 value variables detected, 4 are concentrated in objective 8 , since they are related to economic growth through employment.

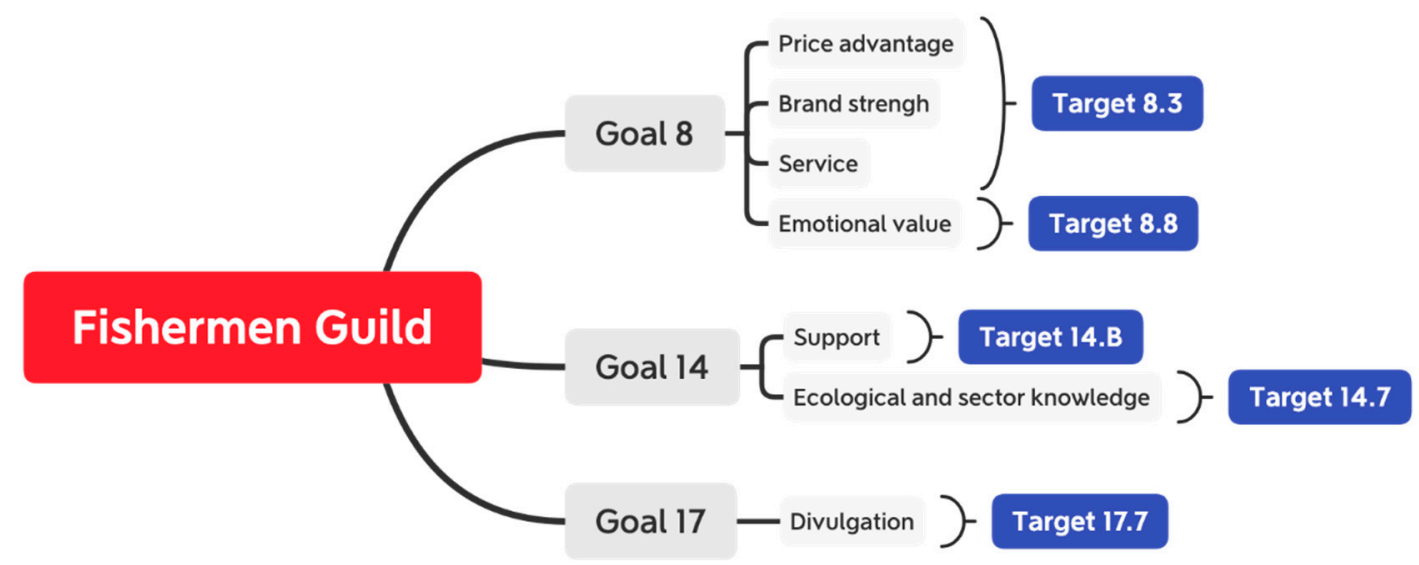

Figure 1. Allocation of the fishermen's guild value variables in the Sustainable Development Goals (SDGs) scheme.

Three of them fall within the target 8.3 as they are aimed at the empowerment of small and medium-sized enterprises, the fishermen, in this case, helping to formalize and maintain them through the services they provide. The variable of emotional value can be located within target 8.8 since its description is in line with the promotion of a safe working environment and the protection of labor rights.

The second SDG to which the guild's value variables are related is number 14, addressing marine conservation. In this case, the support it provides to artisanal fisheries clearly places it in the environment of goal 14.B, while the collaboration it carries out together with the National Oceanographic Institute contributes to the achievement of what is established in target 14.7 for more sustainable use of marine resources.

Finally, the outreach work carried out by the guild allows associating its activity with Goal 17, given the different agreements with public and private institutions in pursuit of sustainability, which is in line with what is stated in target 17.17. 


\subsubsection{Agrarian Transformation Societies}

The greater connectivity of the SAT with the social fabric, its larger size, and its greater variety of activities means that these have an impact on a larger number of SDGs than the guild, as can be seen in Figure 2. Nevertheless, SDG number 8 concentrates almost $50 \%$ (7 out of the 18) of the identified value variables. Two of them, regulation and market expansion and the presence of a cooperative spirit and internal solidarity, are linked to target 8.3 since they promote the development of small companies through various actions.

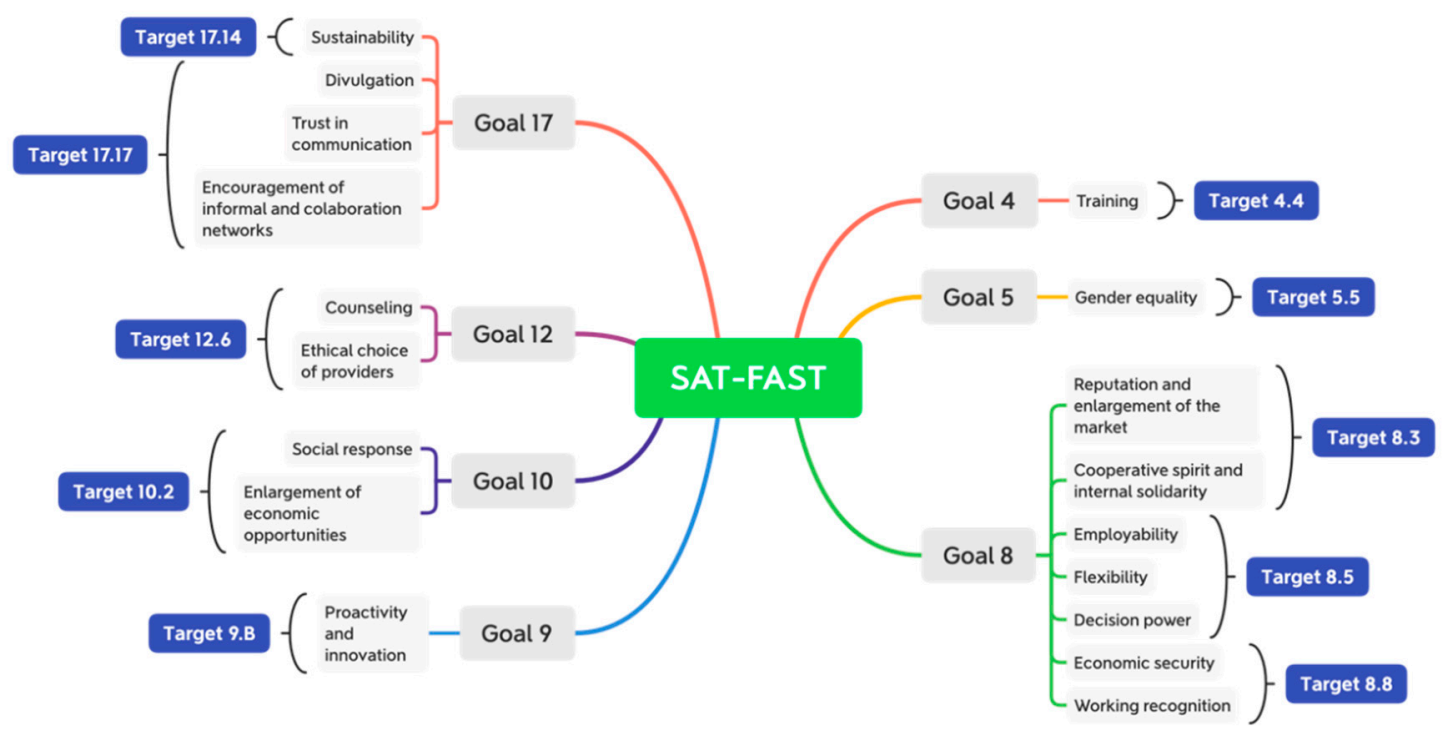

Figure 2. Allocation of the SAT's value variables in the SDGs scheme.

The quality of employment in the organization, it is grouped under target 8.5 , focused on creating decent employment conditions for all groups. Aspects such as the employability of people with disabilities and at risk of exclusion through Special Employment Centers and Insertion Companies, the flexibility that their workers enjoy, and the decision-making capacity fit in with what is stated in that target. Finally, within Goal 8, economic security and labor recognition are in line with the protection of labor rights and the creation of safe workspaces established in target 8.8.

The next goal that brings together the greatest number of value variables is 17 , referring to associations for sustainable development. Here, the sustainability variable falls within target 17.14, since the work of the SAT has a multiplier effect that favors the use of sustainability policies among the different entities with which it works, the organization being a model to follow. The creation of communication and information networks, which is summarized in the variables of divulgation, trust in communication, and formal and informal networks of collaboration are within the aspirations of target 17.17, which seeks to promote precisely public-private collaboration.

In addition to these two SDGs, which together concentrate more than half of the variables, the SAT activity can be assigned to five more SDGs. In numerical order, the first of them would be SDG 4, referring to training, where the training variable contributes to the achievement of target 4.4, aimed to increase the part of the population with access to skills relevant to employment. The recognized work on gender equality carried out by the entity is within the precepts of SDG number 5, and more specifically in target 5.5 dedicated to ensuring the participation of women in decision-making and equality at work.

The proactivity and innovation that the SAT stakeholders' value is part of what is contained in SDG 9, dedicated in part to promoting innovation. The contribution of these actions is focused on target 9.5, which includes support for the development of nearby technologies, a fact that the organization favors thanks to its entrepreneurship and continuous improvement policies. 
The variable of social response and expansion of economic opportunities are aligned with SDG 10, aimed at reducing inequalities. The continued contribution of resources to the third sector and public sector entities that work in this field helps the social inclusion of different groups, who are directly or indirectly favored, and has a positive impact on the aspirations included in target 10.2.

Finally, the counseling and ethical choice of suppliers has a multiplying effect in the expansion of sustainability policies throughout the SAT value chain, which promotes (or forces in the case of suppliers) the implementation of models of more sustainable production and consumption. This contributes directly to SDG 12, and specifically on target 12.6, which seeks to encourage the inclusion of more information on sustainability practices in company reports. The fact of having undergone the process of monetization of social value is another of the contributions made by the organization since its role as a pioneer in this field will have a positive driving effect that will make more similar or related entities decide to implement it as well.

\subsection{Quantifying the Contribution of Each Entity to the SDGs}

The next step in this section is to quantify in monetary terms the contribution each entity makes to the SDGs. The starting point to do so are the results of the monetization process of the non-market social value collected for each organization that can be seen in Table 4.

Table 4. Results of the monetization process of the non-market social value collected.

\begin{tabular}{|c|c|c|c|}
\hline $\begin{array}{l}\text { Value Variable } \\
\text { Fishermen's Guild }\end{array}$ & Generated Value & Value Variable SAT & Generated Value \\
\hline Service & $13,545.52 €$ & Social response & $170,672.33 €$ \\
\hline Price advantage & $22,729.20 €$ & Divulgation & $6,399.00 €$ \\
\hline Divulgation & $2,730.60 €$ & Counseling & $24,007.95 €$ \\
\hline Support & $22,955 €$ & Employability & $20,520.00 €$ \\
\hline $\begin{array}{l}\text { Ecological and sector } \\
\text { knowledge }\end{array}$ & $15,700 €$ & Economic security & $137,902.61 €$ \\
\hline Brand strength & $13,140 €$ & $\begin{array}{l}\text { Expanding economic } \\
\text { opportunities }\end{array}$ & $748,89 €$ \\
\hline \multirow[t]{12}{*}{ Total } & $90,800 €$ & Sustainability & $47,466.68 €$ \\
\hline & & $\begin{array}{l}\text { Reputation and expansion } \\
\text { of the market }\end{array}$ & $10,530.00 €$ \\
\hline & & $\begin{array}{l}\text { Fostering informal and } \\
\text { collaborative networks }\end{array}$ & $60,870.00 €$ \\
\hline & & $\begin{array}{l}\text { Confidence and fluidity of } \\
\text { communication }\end{array}$ & $30,460.37 €$ \\
\hline & & Job recognition & $8,600.00 €$ \\
\hline & & Training & $20,203.20 €$ \\
\hline & & Flexibility & $81,900.00 €$ \\
\hline & & Decision power & $26,400.00 €$ \\
\hline & & Gender equality & $300,000.00 €$ \\
\hline & & $\begin{array}{l}\text { Cooperative spirit and } \\
\text { internal solidarity }\end{array}$ & $88,844.76 €$ \\
\hline & & Ethical choice of providers & $6,359.25 €$ \\
\hline & & Total & $1,055,885.04 €$ \\
\hline
\end{tabular}

Given the difference in size in the number of workers and turnover of both organizations, to favor the comparison, this has been made in terms of percentage contribution. In the case of the guild (Figure 3), SDG number 8 concentrates more than half of the value generated (54.42\%), due to the fact that the price and service advantage variables together account for more than a third of that value. The activity related to maritime conservation is reflected in the significant weight of SDG 14, which reaches $42.17 \%$ of the total, while the collaborative part of the guild, which is included in SDG 17 , is more residual and it reaches $3.01 \%$. 


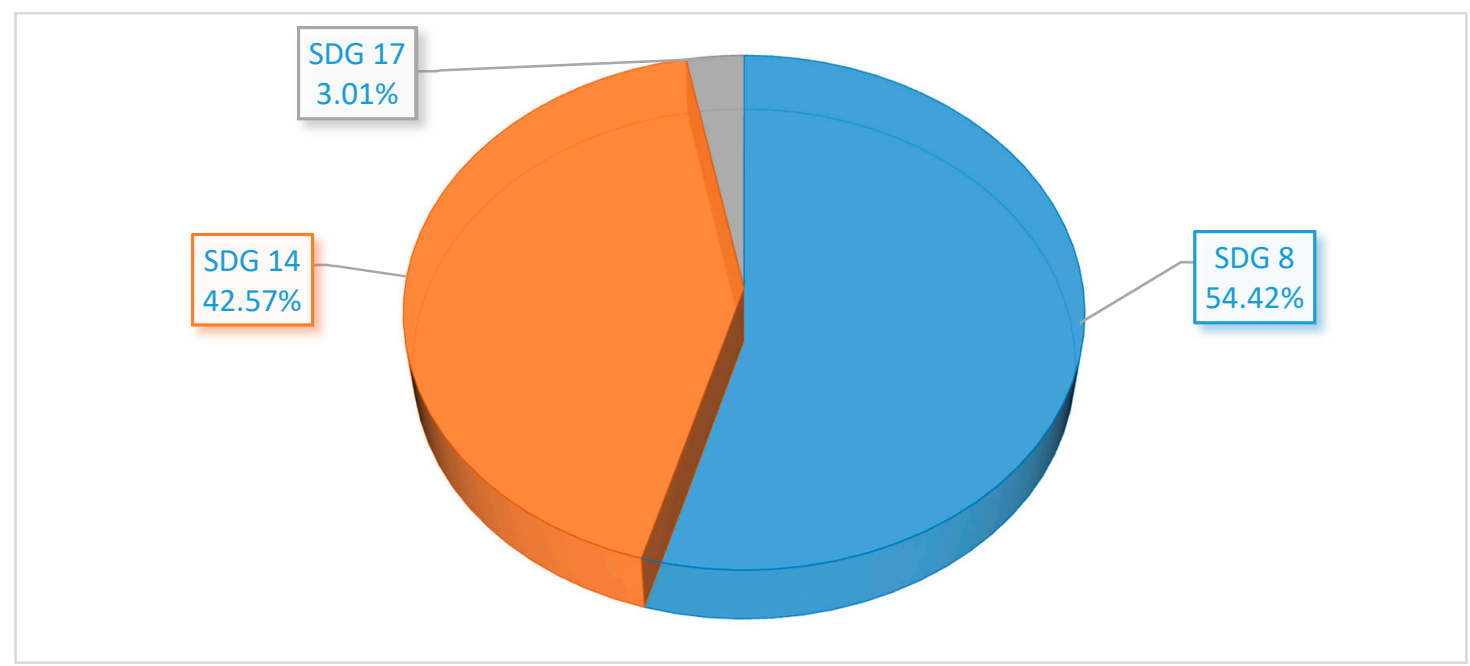

Figure 3. Percentage distribution by SDG of the non-market social value of the fishermen's guild.

The value generated by the SAT is more distributed in percentage terms and several SDGs exceed $15 \%$ (Figure 4 ). As in the previous case, SDG 8 brings together a large part of the entity's social value, $35.49 \%$, as a result of variables such as economic security and flexibility, to which workers give great importance. The contribution to SDG 5 on gender equality is also remarkable. Although a single homonymous variable has been located in it, the valuation granted to it by the Cabildo de Tenerife, $€ 300,000$, increases its weight within the total set. The third place in importance is occupied by SDG 10 where the contribution of the SAT to the development of social and non-profit entities is valued at almost $€ 18,000$ and raises the relative importance to $16.23 \%$ of the total.

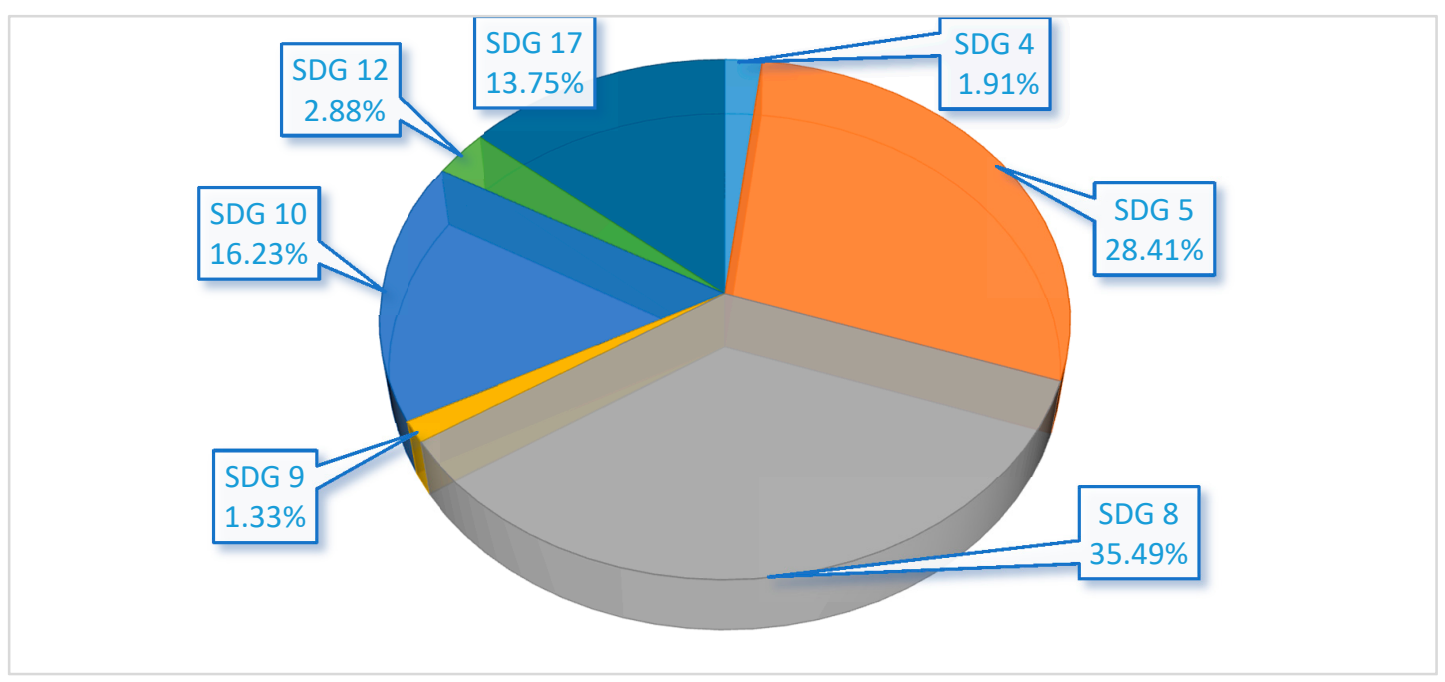

Figure 4. Percentage distribution by SDG of the non-market social value of the SAT.

The collaborative nature of the entity is reflected in the proportion of SDG 17 (13.75\%), due to the variables of promoting networks and communication. This highlights the relevance that this type of strategy has for the stakeholders of the organization and the value of its contribution in this regard. Finally, there are 3 SDGs that do not exceed 3\% of importance, such as SDG 12 (2.88\%), which includes the counseling variable, SDG 4, where training is valued, and SDG 9, which reflects the value that it is given the proactivity and innovation that the entity fosters.

A series of similarities and differences can be drawn between these two types of Social Economy companies that can serve as a basis for a broader comparison in the future. First, the Fishermen's Guild, unlike the SAT, focuses its value generation more on objectives directly related to its activity-SDG 
14 in this case-and on aspects related to employment. Those issues have less impact in the case of the SAT, where their collaborative spirit permeates more in society, which translates into a greater contribution to the SDGs such as number 17 related to such activities.

\subsection{The Relationship between the Stakeholders and the SDGs}

The last section of the analysis includes the relationship between the contribution to the SDGs and the different interest groups that have been involved in the process of monetizing the social value of both entities. Derived from this process, there is a matrix of stakeholder interests for each of the entities (see Appendix B), which allows each of the non-market value variables to be related cross-sectionally with various groups. Starting on the classification of the value variables for each SDG previously explained, a similar process can be carried out that directly relates each Goal with the different stakeholders of the organizations.

\subsubsection{Fishermen's Guild}

As can be seen in Figure 5, of the three SDGs to which the company's actions contribute, SDG 8 concentrates two-thirds of the stakeholders that have been considered. Public entities such as local government and private entities such as shipmasters and providers are included in there. The other two SDGs, the 14th and the 17th bring together three agents, among which the local government is present in the three Goals. SDG 14 includes agents exclusively from the public sector, while 17 includes agents with a more direct relationship with the guild such as boat owners and fishermen.

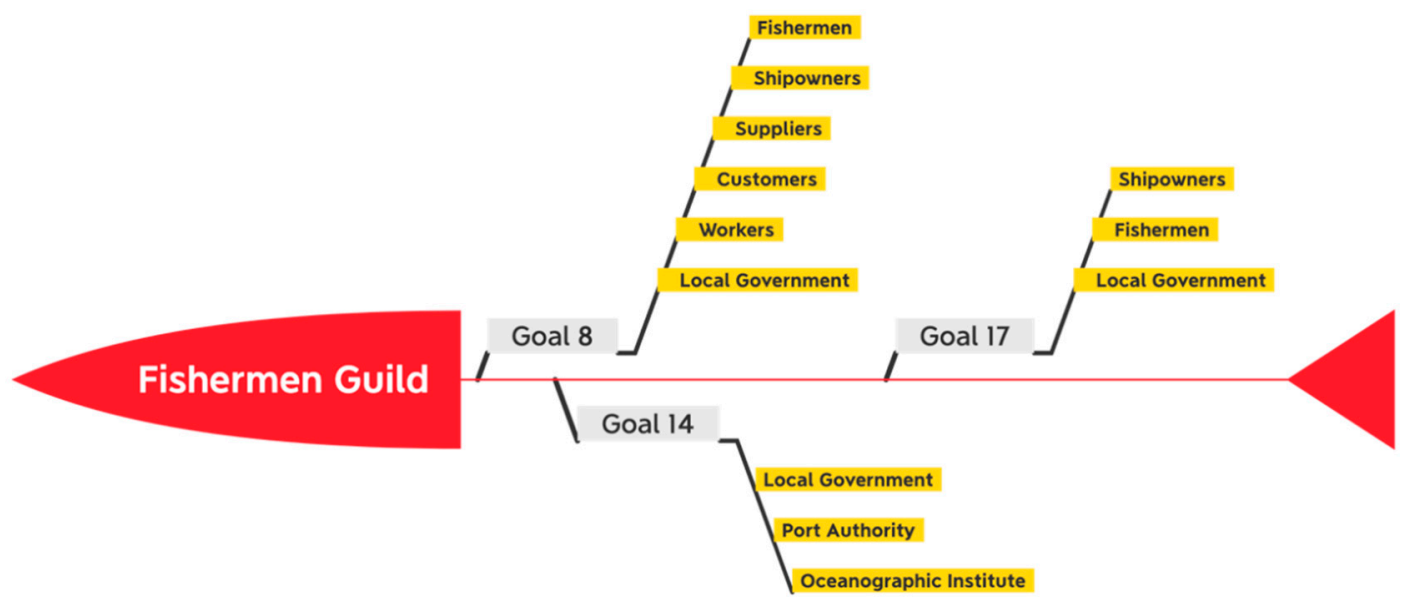

Figure 5. Relationship between the different stakeholders and the SDGs for the fishermen's guild.

\subsubsection{Agrarian Transformation Societies}

As can be seen in Figure 6, SDGs 8 and 17 are those that present a greater variety of stakeholders associated with them through the expressed value variables. Furthermore, there is a coincidence in most of the agents present in both Goals, which reaffirms that the vision of SAT's contribution to sustainability is focused on providing decent economic growth and that its presence is a great incentive for the creation of networks that support a necessary change in the production and society model. 


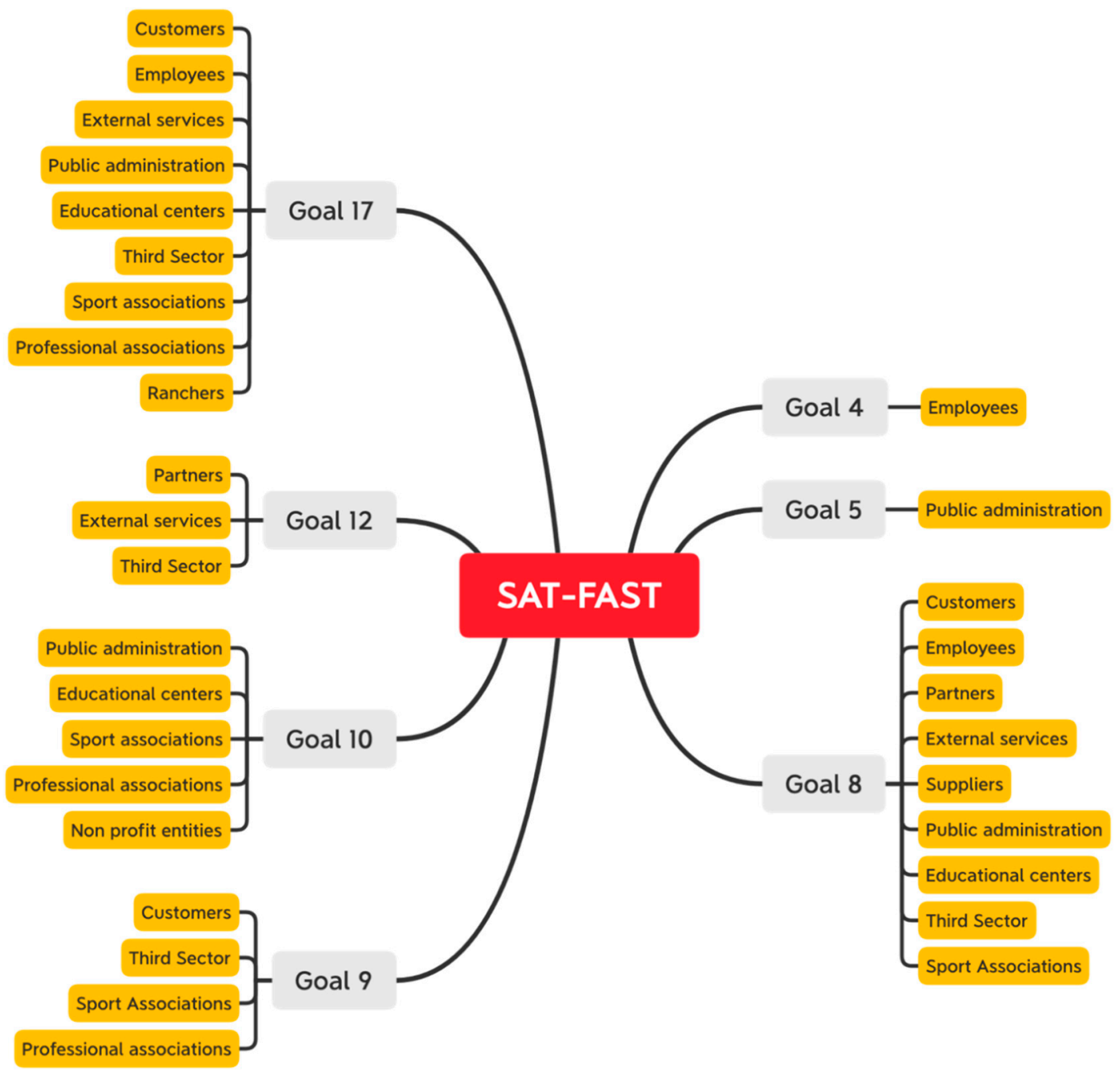

Figure 6. Relationship between the different stakeholders and the SDGs for the SAT.

Also noteworthy is the presence of more than three stakeholders in both SDG 9 and SDG 10, which has both professional and sports associations in common. The proactivity and innovation that is part of SDG 9 are perceived above all by associations and customers, while the social response and the improvement of opportunities are valued by the public, private and the third sector.

It is interesting to appreciate how, despite the efforts made by the entity to guarantee equality and promote activities in this regard which are included in its various CSR reports, only one of the stakeholders explicitly values that contribution. Consequently, the SDG 5 about gender equality has the least number of stakeholders associated (along with SDG 4), although, as previously mentioned, the percentage contribution to the total in monetary terms is the second highest.

\section{Discussion}

The use of the results extracted from Social Accounting in the framework of the SDG allows the generation of an information system on the effective contribution that the activities of the different entities have on sustainability. Throughout this article, the importance of the monetization of the social value of organizations for strategic decision-making in the ethical and sustainability fields has been highlighted. Its integration into the business strategy will make it easier for organizations to make decisions to take action towards achieving the 2030 SDGs.

The contribution of both the fishermen's guild and the SAT to the SDGs focuses, above all, on Goal 8, which is related to economic growth and quality employment. It is precisely this last factor, 
employment, where this type of entity seems to have a greater impact. However, the variables that bear this impact are of a different nature, since in the case of the SAT they are much more focused on workers, while in the case of the guild it is more related to the services it provides to its members.

The principles of Social Economy that govern the organizations analyzed are reflected in their contribution to the SDGs. On the guild' side, the input to the sector in which it carries out its activity is reflected in the weight of Goal 14. On the other side, the greater size and diversity of SAT activities translates into a strong contribution to Goal 17, aimed at the creation of alliances for sustainability. The importance of cooperative nature is also reaffirmed with the contribution to Goal 12, which shows the influence that SAT can have throughout its value chain with the expansion of sustainability policies.

At this point, it should be noted that the fact that SAT has been the pioneer in undergoing the process of monetization of the social value that it generates to its stakeholders, enhances its role as a benchmark among its associations. This carries a positive driving effect in similar entities or others with which it is related so that these organizations could decide to monetize the generation of their social value.

The size of the organization, its contact networks, and the sustainability policies implemented can be considered as factors that decisively influence the contribution that each entity makes to the SDGs. In the case of the guild, this impact is more noticeable in the economic sector where it operates. In the case of the SAT, there is a greater influence of the size and diversity of activities, which translates into a greater variety of SDGs to which it contributes.

One of the fundamental arguments of Social Accounting is that the stakeholders are in charge of evaluating the activities of each entity, which means reverting the traditional concept of Corporate Social Responsibility whose focus is more focused on the organization. One of the most innovative contributions made by the study is to draw a map of the relationship between the impact produced in the SDG and the perception of stakeholders. The distribution of these with respect to the SDGs follows a structure similar to that of the economic value provided by companies. Thus, in both the guild and the SAT, most of them focus on Goal 8, although Goal 17 is highly relevant.

Knowing this information can be very useful for entities from a strategic point of view, not only to adapt their activities based on the perceptions that different stakeholders have but also in terms of communication. From a legal point of view, the information extracted can be used to comply with the requirements of non-financial information that European Directive 2014/95/EU regulates and that in Spain has been transposed into Law 11/2018, of 28 of December, amending the Commercial Code, the consolidated text of the Capital Companies Law approved by Royal Legislative Decree 1/2010, of July 2, and Law 22/2015, of July 20, of Accounts Audit, in matters of non-financial information and diversity.

Regarding the contribution to scientific knowledge, this work expands the orientation and reporting frameworks of the SDGs for Social Economy entities using the SPOLY model of Social Accounting, a model that is estimated to be effective in achieving the stated, participatory and transparent purpose. The foundations of this system make it possible to obtain relevant indicators with which organizations can guide their action towards the SDGs. Likewise, unlike the other frameworks, the stakeholder participation process is standardized, ensuring in-depth dialogue with stakeholders. Third, since the methodological stages are standardized and the monetization process is documented, traceability is also ensured and, consequently, transparency. Finally, within the SPOLY model, this work is a contribution, it opens the door: the connection of the value variables and the SDGs had not yet been published.

Therefore, the study advances in the quantification of the effective contribution to the sustainability of the Social Economy. The findings of the article can help to clarify how the actions of the different entities link with the SDG not only conceptually, but also measuring the distribution among them. This is different from the already in place Global indicator framework for the Sustainable Development Goals and targets proposed by the United Nations [35], which are conceived mainly for the national and supranational levels and are still developing. The results provide, as well some clarification on the 
measuring of social sustainability, which is still in a lesser degree of development than the economic and environmental dimensions. This is also done taking as a reference an internationally recognized and accepted framework, which can help the comparison with other types of entities both within and outside the Social Economy. Thus, providing a basis for the future development of a system of indicators that can be systematized and extrapolated with less use of resources and effort.

There are also some limitations to the study. The reduced size of the sample, two organizations, implies that more analysis is needed to build a proper framework to allow comparison within the same "family" of the Social Economy and with other entities. Together with that, the data used for the quantification is extracted from the Social Accounting process, which slows the process since it needs to be carried out first. Another of the limits that can be pointed out is that there is not yet a well-developed theoretical framework to connect the value variables obtained in the Social Accounting process and the SDGs.

Second, the subjective approach to objectify the social value on which it is based, and the stage of development in which the model is located, makes difficult at the moment a direct application to other entities of the value variables and the proposed indicators and proxies for their monetization, For this, it would be necessary to have a sufficient set of case studies from which to extract a common table of value variables and, for their monetary quantification, adapt the value of the proxy to the reality of each entity, until it counts with standardized ranges. Therefore, this aspect limits comparability between organizations belonging to the same family of the social economy, a requirement urged on the indicators used in the non-financial report.

For the future lines of research, the study of more entities (not only) of the Social Economy would pave the way towards a necessary process of normalization that would both, strengthen the theoretical fundamentals of the proposed methodology and ease its application in the future. The comparison of organizations of different nature and productive sectors (for instance, between profit and nonprofit organizations) is another path to follow and it would allow building a more robust system of indicators that complement the existing ones at the international level.

Author Contributions: Conceptualization, J.M.J., B.G.P., M.V.P.M. and C.R.C.; methodology, J.M.J., B.G.P., M.V.P.M. and C.R.C.; validation, J.M.J., B.G.P., M.V.P.M. and C.R.C.; formal analysis, J.M.J., B.G.P., M.V.P.M. and C.R.C.; investigation, J.M.J., B.G.P., M.V.P.M. and C.R.C.; resources J.M.J., B.G.P., M.V.P.M. and C.R.C.; data curation, J.M.J., B.G.P., M.V.P.M. and C.R.C.; writing-original draft preparation, J.M.J., B.G.P., M.V.P.M. and C.R.C.; writing-review and editing, J.M.J., B.G.P., M.V.P.M. and C.R.C.; supervision, J.M.J., B.G.P., M.V.P.M. and C.R.C.; funding acquisition, J.M.J., B.G.P., M.V.P.M. and C.R.C. All authors have read and agreed to the published version of the manuscript.

Funding: This research received no external funding.

Conflicts of Interest: The authors declare no conflict of interest.

\section{Appendix A}

Table A1. Description of value variables of the fishermen's guild.

\begin{tabular}{ll}
\hline Value Variables & Description \\
\hline \multirow{3}{*}{ Service } & $\begin{array}{l}\text { It collects the value for the ship owners and sailors of the advice, } \\
\text { the processing of documents by the Social Institute of the Navy } \\
\text { and information on aid and subsidies from the Vice counsel of } \\
\text { Fishing; the centralization of purchases, to shipowners; and the } \\
\text { dry dock service, to customers and ship owners. }\end{array}$ \\
\hline & $\begin{array}{l}\text { Members and clients obtain profit by acquiring products at a } \\
\text { lower price than the market: ship owners, footwear, boat cleaning } \\
\text { Price advantage } \\
\text { and the travel lift; the set of partners, and customers and partners, } \\
\end{array}$ \\
\hline
\end{tabular}


Table A1. Cont.

\begin{tabular}{ll}
\hline Value Variables & Description \\
\hline Divulgation & $\begin{array}{l}\text { It includes the transfer of the reality of the sector and the } \\
\text { problems of the confreres to the Vice counsel of Fishing, } \\
\text { appreciated by the members. It also includes the utility for the } \\
\text { Vice counsel of Fishing and the Social Institute of the Navy of the } \\
\text { data that the entity registers and communicates. }\end{array}$ \\
\hline Vupport & $\begin{array}{l}\text { Value for the Vice counsel of Fishing and the Port Authority of the } \\
\text { work of the entity of surveillance and conservation of the public } \\
\text { infrastructures granted for its exploitation and the support for the } \\
\text { implementation of the common fisheries policy, as well as that } \\
\text { provided to the teams of investigation. }\end{array}$ \\
\hline Ecological and sector knowledge & $\begin{array}{l}\text { Usefulness for the Vice counsel of Fishing to have direct } \\
\text { information on the reality of the sector and for the Canary Islands } \\
\text { Oceanographic Institute for the possibility of having the } \\
\text { knowledge of fishermen. }\end{array}$ \\
\hline Brand strength & $\begin{array}{l}\text { Positive impact on the image of suppliers due to the use of filters } \\
\text { and fire extinguishers purchased by the brotherhood. }\end{array}$ \\
\hline Emotional value & Satisfaction for work staff to be part of the entity. \\
\hline
\end{tabular}

Table A2. Description of value variables of the fishermen's guild.

\begin{tabular}{|c|c|}
\hline Value Variables & Description \\
\hline Social response & $\begin{array}{l}\text { The continuous and permanent contribution of tangible and } \\
\text { intangible resources by the SAT to the agents of the third sector of } \\
\text { social action and non-profit, Public Administrations, educational } \\
\text { centers, sports associations, and professional associations, allows } \\
\text { and facilitates these organizations to carry out their mission. }\end{array}$ \\
\hline Divulgation & $\begin{array}{l}\text { Public Administration agencies, professional associations and } \\
\text { entities from the third sector of social action value the } \\
\text { participation of SAT in its initiatives and projects, since they make } \\
\text { them more widely known and have social repercussions. }\end{array}$ \\
\hline Counseling & $\begin{array}{l}\text { The insertion agents of the third sector of social action and the } \\
\text { associates value the disinterested orientation provided by the SAT, } \\
\text { either in labor aspects or technical-agricultural advice, } \\
\text { respectively. }\end{array}$ \\
\hline Employability & $\begin{array}{l}\text { The entities of the third sector of social action and Public } \\
\text { Administration organisms obtain profits from the contribution } \\
\text { made by the SAT to the labor inclusion of people with disabilities. }\end{array}$ \\
\hline Economic security & $\begin{array}{l}\text { The organization provides economic certainty to the different } \\
\text { groups with which it is related: workers, through quality } \\
\text { employment and internal promotion; associates, ensuring the } \\
\text { collection and sale of agricultural production at a good price; and } \\
\text { entities of the third sector of social action and educational centers, } \\
\text { attending to the needs that arise. }\end{array}$ \\
\hline Expanding economic opportunities & $\begin{array}{l}\text { The entities of the third sector of social action value the activities } \\
\text { of the SAT that make it possible for families with less purchasing } \\
\text { power to access the consumption of healthy food. }\end{array}$ \\
\hline Sustainability & $\begin{array}{l}\text { Clients, educational centers, third sector entities of social action, } \\
\text { sports centers and professional associations value the positive } \\
\text { effect of the entity's actions in the different dimensions of } \\
\text { sustainability. }\end{array}$ \\
\hline
\end{tabular}


Table A2. Cont.

\begin{tabular}{|c|c|}
\hline Value Variables & Description \\
\hline $\begin{array}{l}\text { Reputation and expansion of the } \\
\text { market }\end{array}$ & $\begin{array}{l}\text { Service outsourcing providers and entities benefit from having } \\
\text { SAT in their client portfolio, by improving its image and } \\
\text { facilitating the establishment of business relationships with other } \\
\text { agents. }\end{array}$ \\
\hline $\begin{array}{l}\text { Fostering informal and collaborative } \\
\text { networks }\end{array}$ & $\begin{array}{l}\text { Suppliers and creditors, service outsourcing entities and workers } \\
\text { value the actions carried out by the SAT that favor the emergence } \\
\text { of informal networks between them. }\end{array}$ \\
\hline $\begin{array}{l}\text { Confidence and fluidity of } \\
\text { communication }\end{array}$ & $\begin{array}{l}\text { The agility, cooperation and closeness of treatment that } \\
\text { characterize the SAT is valued by Public Administration agencies, } \\
\text { providers and creditors, service outsourcing entities, the third } \\
\text { sector of social action and workers. }\end{array}$ \\
\hline Job recognition & $\begin{array}{l}\text { The SAT team values that the entity's management shows a } \\
\text { distinction for a job well done. }\end{array}$ \\
\hline Training & Workers value training and professional development actions. \\
\hline Flexibility & $\begin{array}{l}\text { The human team values that the entity makes possible the } \\
\text { reconciliation of family, personal and professional life. }\end{array}$ \\
\hline Decision power & Workers value having a certain autonomy in decision making. \\
\hline Gender equality & $\begin{array}{l}\text { Public Administration bodies value SAT's commitment and } \\
\text { involvement in promoting gender equality, both in their own } \\
\text { workforce and in the Canary Islands society }\end{array}$ \\
\hline $\begin{array}{l}\text { Cooperative spirit and internal } \\
\text { solidarity }\end{array}$ & $\begin{array}{l}\text { The members, workers, sports centers and associations and } \\
\text { entities of the third sector of social action value that the principles } \\
\text { of behavior of the SAT are the distributive balance, the } \\
\text { prioritization of social values and cooperativism. }\end{array}$ \\
\hline Ethical choice of providers & $\begin{array}{l}\text { Suppliers and creditors and service outsourcing entities recognize } \\
\text { that the social response, characteristic of the actions of both } \\
\text { parties, positively affects mutual trust. }\end{array}$ \\
\hline Proactivity and innovation & $\begin{array}{l}\text { Entrepreneurship and continuous improvement of the SAT are } \\
\text { aspects valued by customers, third sector entities of social action } \\
\text { and sports centers and associations. }\end{array}$ \\
\hline
\end{tabular}

\section{Appendix B}

Table A3. Fishermens' guild stakeholders' variable matrix.

\begin{tabular}{|c|c|c|c|c|c|c|c|c|c|}
\hline \multirow{2}{*}{ Value Variables } & \multicolumn{9}{|c|}{ Stakeholders $(*)$} \\
\hline & FM & SO & SP & WO & CL & VF & IM & $\mathbf{A P}$ & OC \\
\hline Service & $x$ & $x$ & & & $x$ & $x$ & & & \\
\hline Price advantage & $\mathrm{x}$ & $x$ & & & $x$ & & & & \\
\hline Divulgation & $x$ & $\mathrm{x}$ & & & & $x$ & $x$ & & \\
\hline Support & & & & & & $x$ & & $x$ & $x$ \\
\hline $\begin{array}{c}\text { Ecological and } \\
\text { sector knowledge }\end{array}$ & & & & & & $x$ & & & $x$ \\
\hline Brand strength & & & $x$ & & & & & & \\
\hline Emotional value & & & & $x$ & & & & & \\
\hline
\end{tabular}


Table A4. SAT' stakeholders' variable matrix.

\begin{tabular}{|c|c|c|c|c|c|c|c|c|c|c|c|c|c|c|c|}
\hline \multirow{2}{*}{ Value Variables } & \multicolumn{15}{|c|}{ Stakeholders $\left({ }^{*}\right)$} \\
\hline & CL & HT & AS & EX & SP & MD & CA & PA & $\mathrm{EC}$ & TS & $\mathrm{SC}$ & PR & NP & $\mathrm{CO}$ & RA \\
\hline Social response & & & & & & & & $x$ & $x$ & $x$ & $x$ & $x$ & $x$ & & \\
\hline Divulgation & & & & & & & & $x$ & & $\mathrm{x}$ & & $x$ & & & \\
\hline Counseling & & & $x$ & & & & & & & $\mathrm{x}$ & & & & & \\
\hline Employability & & & & & & & & $x$ & & $\mathrm{x}$ & & & & & \\
\hline $\begin{array}{l}\text { Economic } \\
\text { security }\end{array}$ & $x$ & $x$ & & & & & & $x$ & $x$ & $x$ & & & & & \\
\hline $\begin{array}{c}\text { Expanding } \\
\text { economic } \\
\text { opportunities }\end{array}$ & & & & & & & & & & $x$ & & & & & \\
\hline Sustainability & $\mathrm{x}$ & & & & & & & & $x$ & $\mathrm{x}$ & $x$ & $x$ & & & $\mathrm{x}$ \\
\hline $\begin{array}{l}\text { Reputation and } \\
\text { expansion of } \\
\text { the market }\end{array}$ & & & $x$ & $x$ & $x$ & & & & & & & & & & \\
\hline $\begin{array}{c}\text { Fostering } \\
\text { informal and } \\
\text { collaborative } \\
\text { networks }\end{array}$ & & $x$ & & $x$ & $x$ & & & & & & & & & & \\
\hline $\begin{array}{l}\text { Confidence and } \\
\text { fluidity of } \\
\text { communication }\end{array}$ & & $x$ & & $x$ & $x$ & & & $x$ & & $x$ & & & & & \\
\hline Job recognition & & $x$ & & & & & & & & & & & & & \\
\hline Training & & $x$ & & & & & & & & & & & & & \\
\hline Flexibility & & $x$ & & & & & & & & & & & & & \\
\hline Decision power & & $x$ & & & & & & & & & & & & & \\
\hline Gender equality & & & & & & & & $x$ & & & & & & & \\
\hline $\begin{array}{l}\text { Cooperative } \\
\text { spirit and } \\
\text { internal } \\
\text { solidarity }\end{array}$ & & $x$ & $x$ & & & & & & & $x$ & $x$ & & & & \\
\hline $\begin{array}{c}\text { Ethical choice of } \\
\text { providers }\end{array}$ & & & $x$ & $x$ & & & & & & & & & & & \\
\hline $\begin{array}{l}\text { Proactivity and } \\
\text { innovation }\end{array}$ & $x$ & & & & & & & & & $x$ & $x$ & $x$ & & & \\
\hline
\end{tabular}

CL: Clients-HT: Human team-AS: Associates-EX: Services Outsourcing-SP: Suppliers/Creditors-MD: Media-CA: Certification and Support Entities-PA: Public Administration-EC: Educational Centers-TS: Third Sector of Social Action-SC: Sports Centers and Associations-PR: Professional Associations-NP: Non-Profit Associations-CO: Consumers-RA: Ranchers.

\section{References}

1. Bono, E. El decrecimiento sostenible, crisis ecológico-económica, desigualdad y economía social. CIRIEC-Esp. Rev. Econ. Pública Soc. Coop. 2012, 76, 180-196.

2. Chaves, R.; Monzón, J.L. Beyond the crisis: The social economy, proposal of a new model of sustainable economic development. Serv. Bus. 2012, 6, 5-26. [CrossRef]

3. Ostrom, E. The institutional analysis and development framework and the commons. Cornell L. Rev. 2009, 95, 807. [CrossRef]

4. Mozas Moral, A.; Bernal Jurado, E. Desarrollo territorial y economía social. CIRIEC-Esp. Econ. Pública Soc. Coop. 2006, 55, 125-140.

5. Bretos, I.; Marcuello, C. Revisiting globalization challenges and opportunities in the development of cooperatives. Ann. Public Coop. Econ. 2017, 88, 47-73. [CrossRef] 
6. Bel Durán, P. Similitudes y diferencias entre las sociedades cooperativas agrarias y las Sociedades Agrarias de Transformación a la luz de los principios cooperativos tras el Congreso de Manchester. REVESCO Rev. De Estud. Coop. 1995, 61, 107-126.

7. Román Cervantes, C. Las Sociedades Agrarias de Transformación en España: Un análisis histórico. CIRIEC-Esp. Econ. Pública Soc. Coop. 2008, 63, 65-87.

8. Du Pisani, J.A. Sustainable development-historical roots of the concept. Environ. Sci. 2006, 3, 83-96. [CrossRef]

9. Mebratu, D. Sustainability and sustainable development: Historical and conceptual review. Environ. Impact Assess. Rev. 1998, 18, 493-520. [CrossRef]

10. Ward, B.; Dubos, R. Only One Earth. The Care and Maintenance of a Small Planet; Penguin Books Ltd.: Harmondsworth, UK, 1972; ISBN 0-14-021601-4.

11. Brundtland, G.H.; Khalid, M.; Agnelli, S.; Al-Athel, S.; Chidzero, B. Our common future. In Earth and Us: Population-Resources-Environment-Development, 1st ed.; Kamal Tolba, M., Biswas, A., Eds.; Butterworth-Heinemann: Oxford, UK, 1987; pp. 29-32.

12. Kirkby, J.; O'keef, P.; Timberlake, L. Sustainable Development: The Earthscan Reader; Earthscan Publications: London, UK, 1995; pp. 1-14.

13. Daly, H.E. Beyond Growth: The Economics of Sustainable Development; Beacon Press: Boston, MA, USA, 1996; ISBN 0-8070-4709-0.

14. Holmberg, J. Policies for a Small Planet. Disasters 1996, 20, 84.

15. Solow, R.M. The economics of resources or the resources of economics. In Classic Papers in Natural Resource Economics; Springer: Berlin/Heidelberg, Germany, 1974; pp. 257-276.

16. Anand, S.; Sen, A. Human development and economic sustainability. World Dev. 2000, 28, $2029-2049$. [CrossRef]

17. United Nations Development Programme. Sustainability and Equity: A Better Future for All; United Nations: New York, NY, USA, 2011; p. 185.

18. Solow, R. An almost practical step toward sustainability. Ekistics 1995, 62, 15-20.

19. Ross, A. Modern interpretations of sustainable development. J. Law Soc. 2009, 36, 32-54. [CrossRef]

20. Barbier, E.B.; Markandya, A.; Pearce, D.W. Sustainable agricultural development and project appraisal. Eur. Rev. Agric. Econ. 1990, 17, 181-196. [CrossRef]

21. Sen, A. El desarrollo como libertad. Gac. Ecol. 2000, 55, 14-20.

22. United Nations General Assembly. The 2030 Agenda for Sustainable Development; United Nations: New York, NY, USA, 2015; p. 35.

23. United Nations Environment Programme. Division of Technology Economics: World Tourism Organization. In Making Tourism More Sustainable: A Guide for Policy Makers; World Tourism Organization Publications: Madrid, Spain, 2005; ISBN 92-844-0821-0.

24. Chaves Ávila, R.; Monzón Campos, J.L. La economía social ante los paradigmas económicos emergentes: Innovación social, economía colaborativa, economía circular, responsabilidad social empresarial, economía del bien común, empresa social y economía solidaria. CIRIEC-Esp. Econ. Pública Soc. Coop. 2018, 93, 5-50. [CrossRef]

25. Grupo de Trabajo Interinstitucional de las Naciones Unidas sobre Economía Social y Solidaria. La Economía Social y Solidaria y el Reto del Desarrollo Sostenible: Un documento de posición elaborado por el Grupo de Trabajo Interinstitucional de las Naciones Unidas sobre Economía Social y Solidaria; United Nations: Genebre, Switzerland, 2014; p. 46.

26. Chaves Ávila, R.; Monzón Campos, J.L. Recent Evolutions of the Social Economy in the European Union; CIRIEC-Université de Liège: Liege, Belgium, 2019.

27. UNTFSSE. Realizing the 2030 Agenda through Social and Solidarity Economy; Position Statement; United Nations Task Force for Social and Solidarity Economy: New York, NY, USA, 2016.

28. Monzón Campos, J.L. Empresas sociales y economía social: Perímetro y propuestas metodológicas para la medición de su impacto socioeconómico en la U.E. Rev. Econ. Mund. 2013, 35, 151-163.

29. Gadrey, J. Identification et Mesure de L'utilité Sociale de L'économie Sociale et Solidaire; Séminaire de l'IES, Institut d'Économie Sociale: Paris, France, 2005.

30. Rahdari, A.; Sepasi, S.; Moradi, M. Achieving sustainability through Schumpeterian social entrepreneurship: The role of social enterprises. J. Clean. Prod. 2016, 137, 347-360. [CrossRef] 
31. Mozas Moral, A. Contribución de las Cooperativas Agrarias al Cumplimiento de los Objetivos de Desarrollo Sostenible. Especial Referencia al Sector Oleícola 2019; Ciriec-España: Valencia, Spain, 2019; p. 123.

32. Puentes Poyatos, R.; del Velasco Gámez, M.M. Importancia de las sociedades cooperativas como medio para contribuir al desarrollo económico, social y medioambiental, de forma sostenible y responsable. REVESCO. Rev. Estud. Coop. 2009, 99, 104-129.

33. Hák, T.; Moldan, B.; Dahl, A.L. Sustainability Indicators: A Scientific Assessment; Island Press: Washington, DC, USA, 2012; ISBN 1-59726-628-0.

34. Meadows, D.H. Indicators and Information Systems for Sustainable Development; The Sustainability Institute: Hartland Four Corners, VT, USA, 1998; p. 95.

35. United Nations. Work of the Statistical Commission Pertaining to the 2030 Agenda for Sustainable Development; United Nations: New York, NY, USA, 2017; p. 25.

36. Lebada, A.; Member states, statisticians address SDG monitoring requirements. IISD Knowledge Sharing Hub. 2016. Available online: http://sdg.iisd.org/news/member-states-statisticians-address-sdg-monitoringrequirements/ (accessed on 1 April 2020).

37. Hák, T.; Janoušková, S.; Moldan, B. Sustainable Development Goals: A need for relevant indicators. Ecol. Indic. 2016, 60, 565-573. [CrossRef]

38. Stafford-Smith, M.; Griggs, D.; Gaffney, O.; Ullah, F.; Reyers, B.; Kanie, N.; Stigson, B.; Shrivastava, P.; Leach, M.; O'Connell, D. Integration: The key to implementing the Sustainable Development Goals. Sustain. Sci. 2017, 12, 911-919. [CrossRef]

39. Olsen, S.; Galimidi, B. Catalog of approaches to impact measurement: Assessing social impact in private ventures. Rockfeller Found 2008, 1, 1-74.

40. Comisión Europea. Métodos Propuestos Para la Medición del Impacto social en la Legislación de la Comisión Europea y en la Práctica Relativa a FESE y EaSI; European Commission: Luxembourg, 2015; p. 88.

41. Global Reporting Initiative. GRI G4 Guidelines 1 Reporting Principles and Standard Disclosures; Global Reporting Initiative. 2015. Available online: https://www2.globalreporting.org/standards/g4/ Pages/default.aspx\#: \{\}:text=Part\%201\%20of\%20G4\%20has,in\%20accordance $\backslash$ T1 \textquoteright $\% 20$ with\% 20the\%20Guidelines (accessed on 17 March 2020).

42. Pacto Mundial Red Española. Guía Sectorial en ODS. Sector Agroalimentario 2018; Pacto Mundial: Madrid, Spain, 2018; p. 88.

43. Felber, C. La Economía del Bien Común; Barcelona: Deusto, Spain, 2012.

44. Honeyman, R. The B Corp Handbook: How to Use Business as a Force for Good. Commun. Dev. 2014, 49, 116-117.

45. Garriga, E. Beyond stakeholder utility function: Stakeholder capability in the value creation process. J. Bus. Ethics 2014, 120, 489-507. [CrossRef]

46. WBCSD/IFC. Medición de Impacto-Marco Metodológico: Metodología Para Entender el Aporte del Sector Empresario a la Sociedad; Geneve: Switzerland, 2008.

47. Retolaza Avalos, J.L.; Ruiz Roqueñi, M.; San José Ruiz de Aguirre, L.; Barrutia Guenaga, J. Cuantificación del valor social: Propuesta metodológica y aplicación al caso de Lantegi Batuak. Zerb. Gizarte Zerb. Aldizkaria. Rev. Serv. Soc. 2014, 55, 17-33. [CrossRef]

48. Ayuso, S. La Medición del Impacto Social en el Ámbito Empresarial; Working document; Catédra Mango, Università Pompeu Fabra: Barcelona, Spain, 2018.

49. Van Zanten, J.A.; Van Tulder, R. Multinational enterprises and the Sustainable Development Goals: An institutional approach to corporate engagement. J. Int. Bus. Policy 2018, 1, 208-233. [CrossRef]

50. Kolk, A.; Kourula, A.; Pisani, N. Multinational enterprises and the Sustainable Development Goals: What do we know and how to proceed? Transnatl. Corp. 2017, 24, 9-32. [CrossRef]

51. Girella, L.; Zambon, S.; Rossi, P. Reporting on sustainable development: A comparison of three Italian small and medium-sized enterprises. Corp. Soc. Responsib. Environ. Manag. 2019, 26, 981-996. [CrossRef]

52. Chang, A.-Y.; Cheng, Y.-T. Analysis model of the sustainability development of manufacturing small and medium-sized enterprises in Taiwan. J. Clean. Prod. 2019, 207, 458-473. [CrossRef]

53. Tsvakirai, C.Z.; Mosikari, T.J. Investigating South Africa's Fresh Peach and Nectarine Value Proposition: Measuring Progress on Achieving Sustainable Consumption in Exports. Sustainability 2020, 12, 2615. [CrossRef]

54. Defourney, J.; Pestoff, V. Images and concepts of the third sector in Europe. Eur. Res. Netw. 2008, 8, 38. 
55. Vidal, I. Social economy. In Third Sector Research; Springer: Berlin/Heidelberg, Germany, 2010; pp. 61-71.

56. Varona, M. Sociedades de Socorros Mutuos. El Mar 1995, 331, 62.

57. Cervera-Paz, Á. Nueve Siglos de las Cofradías de Pescadores. Revista de Historia Naval 1998, 61, 81-86.

58. Cervera Paz, Á. Percepción cooperativa de las cofradías de pescadores: Un estudio empírico. REVESCO: Rev. Estud. Coop. 2010, 103, 7-32.

59. Defourny, J.; Develtere, P. L'économie sociale au Nord et au Sud; De Boeck: Bruxelles, Belgium, 1999; pp. $17-47$.

60. De Mendiguren, J.C.P.; Etxarri, E.E.; Aldanondo, L.G. ¿De qué Hablamos Cuando Hablamos de Economía Social y Solidaria? Concepto y Nociones Afines; Cáritas Burgos: Burgos, Spain, 2008; p. 26.

61. Comisión Europea. Comunicación de la Comisión al Parlamento Europeo, al Consejo, al Comité Económico Social Europeo y al Comité de las Regiones. Crecimiento azul. Oportunidades Para un Crecimiento Marino y Marítimo Sostenible; Comisión Europea: Bruselas, Belgium, 2012; p. 16.

62. Boza Vindel, C. Pesca Artesanal de la isla de Tenerife (Canarias): Análisis de la Primera Venta de los Productos Pesqueros y su Influencia en el Registro de Datos Biológicos. Ph.D. Thesis, Universitat d'Alacant, Alicante, Spain, 2015.

63. Fernández, J.P. Los estudios de antropología de la pesca en España: Nuevos problemas, nuevas tendencias. Etnográfica 1999, 3, 333-359.

64. Vargas Vasserot, C. Las sociedades agrarias de transformación en España. Defectos legales y ventajas operativas. Estud. Agrar. 2009, 15, 75-107.

65. Carbonell de Masy, R.; Paniagua Gil, J. Grupos Sindicales de Colonización. Estud. Coop. 1974; 19-32.

66. ISTAC Instituto Canario de Estadística, Estadísticas de Territorio y Medioambiente. Available online: http://www.gobiernodecanarias.org/istac/estadisticas/territorioymedioambiente/ (accessed on 3 May 2020).

67. Suárez de Vivero, J. Changing maritime scenarios. The geopolitical dimension of the EU Atlantic Strategy. Mar. Policy 2014, 48, 59-72. [CrossRef]

68. Popescu, I.; Gras, J.J.O. Fisheries in the Canary Islands; Publications Office of the European Union: Brussels, Belgium, 2013; ISBN 92-823-4314-6.

69. Santamaría, M.; Jiménez, S.; González, J.F.; Falcón, J.M.; Villegas, N. Proyecto GEPETO. Resultados del Caso de Estudio 7: Pesquerías Artesanales de las Islas Canarias. Tenerife; Instituto Español de Oceanografía. Centro Oceanográfico de Canarias: Tenerife, Spain, 2014; p. 106.

70. INE Instituto Nacional de Estadística, FRONTUR. Available online: https://www.ine.es/dyngs/INEbase/es/ operacion.htm?c=Estadistica_C\&cid=1254736176996\&menu=ultiDatos\&idp=1254735576863 (accessed on 10 April 2020).

71. Exceltur; Gobierno de Canarias. IMPACTUR Canarias 2017: Estudio del Impacto Económico del Turismo; Exceltur: Madrid, Spain, 2018; p. 39.

72. Cervera Paz, Á. Análisis Estratégico de las Cofradías de Pescadores Dentro del Marco de la Economía Social. Ph.D. Thesis, Universidad de Cádiz, Cádiz, Spain, 2006.

73. FAO. El Estado Mundial de la Pesca y la Acuicultura 2016. Contribución a la Seguridad Alimentaria y la Nutrición Para Todos; Organización de las Naciones Unidas para la Alimentación y la Agricultura (FAO): Rome, Italy, 2016; p. 224. ISBN 978-92-5-309185-0.

74. Botana Agra, M.J.; Millán Calenti, R.A. Cofradías de pescadores. CIRIEC-Esp. Econ. Pública Soc. Coop. 2016, 29, 117-146.

75. Calderón Gil, C.J. Análisis de la Gestión Socio-Ambiental Por Parte de las Cofradías de Pescadores en la Comunidad Valenciana. Master Thesis, Universtitat Politécnica de Valencia, Valencia, Spain, 2018.

76. Méndez, M.M.D. Las cofradías de pescadores como organizaciones pesqueras y su influencia socioeconómica en la pesca de bajura en España. In Alimentación y Bebidas; Ortega Burgos, E., Muñoz de Cal, E., Eds.; Thomson Reuters Aranzadi: Madrid, Spain, 2018; Volume 2, pp. 307-321.

77. Vidal, D.; Pita, P.; Freire, J.; Muiño, R. Understanding Fishermen-Scientist Collaboration in Galician Small-Scale Fisheries (NW Spain): Validating a Methodological Toolbox Through a Process-Oriented Approach. In Collaborative Research in Fisheries; Springer: Berlin/Heidelberg, Germany, 2020; pp. 61-84.

78. Consejo Económico y Social de Canarias. Informe Anual 2019 del CES Sobre la Situación Económica, Social y Laboral de Canarias en 2018; Colección de Informes Anuales; CES: Canarias, Spain, 2019; p. 440.

79. Instituto Nacional de Estadística Contabilidad Regional de España. Revisión Estadística 2019. Producto Interior Bruto Regional. Serie 2000-2018. Available online: https:/www.ine.es/dyngs/INEbase/es/operacion. htm?c=Estadistica_C\&cid=1254736167628\&menu=ultiDatos\&idp=1254735576581 (accessed on 1 April 2020). 
80. Galván Tudela, J.A. Aspectos sociológicos de las comunidades pesqueras canarias. In Jornadas de Estudios Económicos Canarios; Instituto de Desarrollo Regional: Albacete, Spain, 1982; pp. 81-96.

81. Ministerio de Agricultura, Pesca y Alimentación. In Plan Estratégico Nacional del Fondo Europeo de la Pesca; Gobierno de España: Madrid, Spain, 2007; p. 154.

82. Ministerio de Agricultura, Pesca y Alimentación. Sociedades Agrrias de Transformación; Ministerio de Agricultura y Pesca, Alimentación y Medioambiente: Madrid, Spain, 2019; p. 3.

83. Cátedra Cajasiete de Economía Social y Cooperativa. Estudio sobre la distribución de la Economía Social en Canarias, Working document; San Cristóbal de La Laguna, Spain, 2019.

84. ISTAC. ISTAC, Estadísticas de Agricultura. Available online: http://www.gobiernodecanarias.org/istac/ temas_estadisticos/sectorprimario/agricultura/agricultura/ (accessed on 16 March 2020).

85. Retolaza, J.L.; San-Jose, L.; Ruíz-Roqueñi, M. Social Accounting for Sustainability: Monetizing the Social Value; Springer: Berlin/Heidelberg, Germany, 2016; ISBN 3-319-13376-4.

86. Ayuso, S.; Sánchez, P.; Retolaza, J.L.; Figueras-Maz, M. Social value analysis: The case of Pompeu Fabra University. Sustain. Account. Manag. Policy J. 2018, 11, 233-252. [CrossRef]

87. Emerson, J.; Bonini, S.; Brehm, K. The blended value map: Tracking the intersects and opportunities of economic. Soc. Environ. Value Creat. 2003, 45, 35-51.

88. Retolaza, J.; Sánchez, P.; Tarifa, P.; Ruiz-Roqueñi, M.; San-José, L.; Ayuso, L. Análisis del Valor Social de la Fundación Formació i Treball: Una Aproximación Monetaria al Cálculo del Valor Social; Working document; Catédra Mango, Università Pompeu Fabra: Barcelona, Spain, 2015; Volume 22.

89. Etxarri, E.E.; de Mendiguren Castresana, J.C.P.; Molina, L.D.; Amozarrain, A.E. Valor social de las cooperativas sociales: Aplicación del modelo poliédrico en la cooperativa para la acogida de menores Zabalduz S. Coop. CIRIEC-Esp. Econ. Pública Soc. Coop. 2018, 93, 155-180. [CrossRef]

90. Retolaza, J.L.; San-José, L. Contabilidad social para la sostenibilidad: Modelo y aplicación. Rev. Contab. Dir. 2016, 23, 159-178.

91. Mishan, E.J.; Quah, E. Cost-Benefit Analysis; Routledge: London, UK; New York, NY, USA, 2007; ISBN 1-134-26814-9.

92. Lewin, K. Action research and minority problems. J. Soc. Issues 1946, 2, 34-46. [CrossRef]

93. Psychologie Economique; Félix, A. (Ed.) Ancienne Libr. Germer Baillière et Cie: Paris, France, 1902; Volume 2.

94. Polkinghorne, D.E. Phenomenological research methods. In Existential-Phenomenological Perspectives in Psychology; Springer: Berlin/Heidelberg, Germany, 1989; pp. 41-60.

95. Husserl, E. Ideas Pertaining to a Pure Phenomenology and to a Phenomenological Philosophy: Second Book Studies in the Phenomenology of Constitution; Springer Science \& Business Media: Berlin/Heidelberg, Germany, 1990; Volume 3, ISBN 0-7923-0713-5.

96. Zadeh, L.A. Fuzzy sets. Inf. Control 1965, 8, 338-353. [CrossRef]

97. Kaufmann, A.; Aluja, J.G.; Pirla, J.M.F. Introducción de la Teoría de los Subconjuntos Borrosos a la Gestión de las Empresas; Milladoiro: Vigo, Spain, 1986; ISBN 84-398-7630-0.

98. Hurwicz, L. Some specification problems and applications to econometric models. Econometrica 1951, 19, 343-344.

99. Giorgi, A.; Giorgi, B. Phenomenology. In Qualitative Psychology; Smith, A., Ed.; Sage: London, UK, 2003; pp. 25-50.

100. Guzmán-Pérez, B.; Mendoza Jiménez, J.; Pérez Monteverde, M.V.; Román Cervantes, C. La monetización del valor social de las cofradías de pescadores de Canarias. In Proceedings of the XVII Encuentro Internacional AECA, Lisbon, Portugal, 22-23 September 2016; ISBN 978-84-16286-26-3.

101. Román Cervantes, C.; Guzmán Pérez, B.; Mendoza Jiménez, J.; Pérez Monteverde, M.V. La sostenibilidad social de las SATs: Una propuesta de indicadores para su evaluación. REVESCO: Rev. Estud. Coop. 2020, 133, 71-80.

102. CEPES. La contribución de la Economía Social a los ODS. $4^{\circ}$ Informe Sobre la Experiencia de las Empresas Españolas de la Economía social en la Cooperación al Desarrollo 2017-2019; Informe sobre la experiencia de las empresas españolas de Economía Social en la Cooperación al desarrollo 2017-2019; CEPES: Madrid, Spain, 2020; p. 97.

103. Committee for the Promotion and Advancement of Cooperatives Transforming our World: A Cooperative 2030, Cooperative Contributions to SDG 8; United Nations: New York, NY, USA, 2020. 
104. Gupta, J.; Vegelin, C. Sustainable development goals and inclusive development. Int. Environ. Agreem. Politicslaw Econ. 2016, 16, 433-448. [CrossRef]

105. Costanza, R.; Daly, L.; Fioramonti, L.; Giovannini, E.; Kubiszewski, I.; Mortensen, L.F.; Pickett, K.E.; Ragnarsdottir, K.V.; De Vogli, R.; Wilkinson, R. Modelling and measuring sustainable wellbeing in connection with the UN Sustainable Development Goals. Ecol. Econ. 2016, 130, 350-355. [CrossRef]

(C) 2020 by the authors. Licensee MDPI, Basel, Switzerland. This article is an open access article distributed under the terms and conditions of the Creative Commons Attribution (CC BY) license (http://creativecommons.org/licenses/by/4.0/). 